\title{
4'-O-methylhonokiol increases levels of 2-arachidonoyl glycerol in mouse brain via selective inhibition of its COX-2-mediated oxygenation
}

\author{
Andrea Chicca ${ }^{1 *}$, Maria Salomé Gachet ${ }^{1}$, Vanessa Petrucci', Wolfgang Schuehly², Roch-Philippe Charles ${ }^{1}$ \\ and Jürg Gertsch ${ }^{1 *}$
}

\begin{abstract}
Background and purpose: 4'-O-methylhonokiol $(\mathrm{MH})$ is a natural product showing anti-inflammatory, anti-osteoclastogenic, and neuroprotective effects. MH was reported to modulate cannabinoid CB2 receptors as an inverse agonist for CAMP production and an agonist for intracellular [Ca2+]. It was recently shown that $\mathrm{MH}$ inhibits CAMP formation via CB2 receptors. In this study, the exact modulation of $\mathrm{MH}$ on CB2 receptor activity was elucidated and its endocannabinoid substrate-specific inhibition (SSI) of cyclooxygenase-2 (COX-2) and CNS bioavailability are described for the first time.

Methods: CB2 receptor modulation ([35S]GTPYS, CAMP, and $\beta$-arrestin) by MH was measured in $h$ CB2-transfected CHO-K1 cells and native conditions (HL60 cells and mouse spleen). The COX-2 SSI was investigated in RAW264.7 cells and in Swiss albino mice by targeted metabolomics using LC-MS/MS.

Results: MH is a CB2 receptor agonist and a potent COX-2 SSI. It induced partial agonism in both the [35S]GTPyS binding and $\beta$-arrestin recruitment assays while being a full agonist in the CAMP pathway. MH selectively inhibited PGE2 glycerol ester formation (over PGE2) in RAW264.7 cells and significantly increased the levels of 2-AG in mouse brain in a dose-dependent manner ( 3 to $20 \mathrm{mg} \mathrm{kg}^{-1}$ ) without affecting other metabolites. After $7 \mathrm{~h}$ from intraperitoneal (i.p.) injection, MH was quantified in significant amounts in the brain (corresponding to 200 to $300 \mathrm{nM}$ ).

Conclusions: LC-MS/MS quantification shows that MH is bioavailable to the brain and under condition of inflammation exerts significant indirect effects on 2-AG levels. The biphenyl scaffold might serve as valuable source of dual CB2 receptor modulators and COX-2 SSIs as demonstrated by additional MH analogs that show similar effects. The combination of CB2 agonism and COX-2 SSI offers a yet unexplored polypharmacology with expected synergistic effects in neuroinflammatory diseases, thus providing a rationale for the diverse neuroprotective effects reported for $\mathrm{MH}$ in animal models.
\end{abstract}

Keywords: 4'-O-methylhonokiol, Endocannabinoids, COX-2, CB2 receptor, Polypharmacology, Partial agonist, Endocannabinoid system, 2-arachidonoyl glycerol, Magnolia grandiflora

\section{Introduction}

4'-O-methylhokiol (MH) is the major bioactive constituent of Magnolia grandiflora L. seed oil and shows pronounced anti-inflammatory, anti-osteoclastogenic, and neuroprotective effects [1-4]. In mouse models, MH prevents LPS-induced memory loss and $\beta$-amyloid (1 to42)

\footnotetext{
* Correspondence: chicca@ibmm.unibe.ch; gertsch@ibmm.unibe.ch ${ }^{1}$ Institute of Biochemistry and Molecular Medicine, NCCR TransCure, University of Bern, Bühlstrasse 28, CH-3012 Bern, Switzerland Full list of author information is available at the end of the article
}

accumulation [2]. Moreover, $\mathrm{MH}$ appears to efficiently attenuate the development of Alzheimer's disease in Tg2576 transgenic mice [3]. The proposed underlying mechanisms appear to be linked to the inhibition of nuclear factor kappa B, the gene expression of inducible nitric oxide synthase and cyclooxygenase-2 (COX-2), as well as cannabinoid type-2 $\left(\mathrm{CB}_{2}\right)$ receptors $[2,5]$. $\mathrm{MH}$ and some derivatives potently inhibit COX-2 with poor selectivity towards the constitutive isoform COX-1 [6,7].

\section{Biomed Central}

(c) 2015 Chicca et al.; licensee BioMed Central. This is an Open Access article distributed under the terms of the Creative Commons Attribution License (http://creativecommons.org/licenses/by/4.0), which permits unrestricted use, distribution, and reproduction in any medium, provided the original work is properly credited. The Creative Commons Public Domain Dedication waiver (http://creativecommons.org/publicdomain/zero/1.0/) applies to the data made available in this article, unless otherwise stated. 
Furthermore, $\mathrm{MH}$ attenuates different signaling cascades related to oxidative stress and MAP kinases, inhibits moderately acetylcholinesterase activity (see [5] for review), and it also acts as positive allosteric $\mathrm{GABA}_{\mathrm{A}}$ receptor ligand [8]. Schuehly et al. [1] for the first time described the relatively potent and selective $\mathrm{CB}_{2}$ receptor binding of $\mathrm{MH}$ and different analogs. $\mathrm{MH}$ was shown to exert an unusual dualistic modulation of $\mathrm{CB}_{2}$ receptor activity, acting as an inverse agonist at the cAMP pathway while behaving as an agonist at increasing the intracellular levels of $\left[\mathrm{Ca}^{2+}\right][1]$. The $\mathrm{CB}_{2}$ receptor inverse agonism on the cAMP pathway was described as the relevant mechanism associated to anti-osteoclastogenesis effects described in mouse RAW264.7 cells and primary human monocytes/macrophages. Other authors recently reported that $\mathrm{MH}$ behaves as a $\mathrm{CB}_{2}$ receptor agonist in the cAMP pathway [9], pointing out discrepancies in receptor assays, which gave impetus to the present in-depth study on the $\mathrm{CB}_{2}$ receptor pharmacology of $\mathrm{MH}$. The main degradation route of endocannabinoids (ECs) is their hydrolysis by fatty acid amide hydrolase (FAAH) (for anandamide (AEA)) and monoacylglycerol lipase $/ \alpha, \beta$-hydrolases (MAGL/ABHDs) (for 2-arachidonoyl glycerol (2-AG)), but ECs might undergo additional enzymatic modifications including oxygenation mediated by COX-2, lipoxygenases (LOXs), and cytochrome P450 (CYP450) [10-12]. Several studies emphasized the relevance of COX-2mediated oxygenation of ECs in vitro and in vivo under specific conditions like inflammation and in FAAH knockout animals [13-15]. EC oxygenation might be particularly relevant in inflammation or tissues that constitutively express the inducible form of COX such as the brain, kidney, and spinal cord [16-18]. Upon COX-2 activity, AEA and 2-AG are converted into prostaglandin ethanolamides (prostamides) and prostaglandin glycerol esters (PG-GEs), respectively $[10,11]$. Prostamides and PG-GEs exert proinflammatory actions probably by interacting with specific targets that are different from cannabinoid and classic prostaglandin receptors. A heterodimeric association between the wild-type prostaglandin F (FP) receptor and an alternative splicing variant (Alt4) of such receptors was identified as molecular target for prostamide $F_{2 \alpha}$ [19]. The hyperalgesic actions of prostamideF $F_{2 \alpha}$ were then confirmed by using selective receptor antagonists which showed antinociceptive effects in vitro and in vivo $[15,20]$. The inhibition of prostamide and PG-GEs formation by COX-2 substrate-specific inhibitors (SSIs) has been reported. Intriguingly, such inhibitors can lead to an increase of AEA and 2-AG levels without affecting the levels of arachidonic acid (AA) and $\mathrm{PGE}_{2}[14,21,22]$. Duggan et al. [14] recently showed that $(R)$-flurbiprofen acts as COX-2 SSI by increasing EC levels and by reducing prostamide formation without affecting $\mathrm{AA}$ and $\mathrm{PGE}_{2}$ levels. In addition, the morpholino amide derivative of indomethacin LM-4131 showed potent anxiolytic effects in several animal models by selectively inhibiting EC oxygenation, increasing levels of AEA and 2-AG in the brain [21]. COX-2 SSI might represent a promising anti-inflammatory strategy to circumvent the typical gastrointestinal and cardiovascular aversive effects of the non-selective COX-2 inhibitors.

Here, we show that $\mathrm{MH}$ and some derivatives exert dual and potentially synergistic actions on the endocannabinoid system (ECS) by acting as central nervous system (CNS) penetrating SSIs of COX-2 and as $\mathrm{CB}_{2}$ receptor agonists. We provide detailed analyses on $\mathrm{CB}_{2}$ receptor signaling and COX-2-mediated oxygenation of ECs by using purified $h$ COX-2, RAW264.7 cells, and LPS-challenged mouse brain.

\section{Methods}

Materials

[Ethanolamine- $\left.1-{ }^{3} \mathrm{H}\right]$-anandamide and $\left[1,2,3-{ }^{3} \mathrm{H}\right]$-2-arachidonyl glycerol were obtained from American Radiolabeled Chemicals (St. Louis, MO, USA), while the $\left[{ }^{3} \mathrm{H}\right]$ CP-55,940 was obtained from PerkinElmer Life Sciences (Waltham, MA, USA). AM630, WIN55-212, AEA, 2AG, DuP-697, arachidonic acid- $d 8$ (5Z,8Z,11Z,14Zeicosatetraenoic-5,6,8,9,11,12,14,15- $d 8$ acid), AEA- $d 4$ (N-(2-hydroxyethyl-1,1,2,2-d4)-5Z,8Z,11Z,14Z-eicosate traenamide) 2-AG- $d 5$ (5Z,8Z,11Z,14Z-eicosatetraenoic acid, 2-glyceryl-1,1,2,3,3-d5 ester), LEA-d4 (N-(2hydroxyethyl-1,1,2,2-d4)-9Z,12Z-octadecadienamide); OEA- $d 4$ (N-(2-hydroxyethyl-1,1,2,2- $d 4$ )-9Z-octadecenamide), PEA-d5 (N-(2-hydroxyethyl)-hexadecanamide-15,15,16,16,16-d5); $\quad \mathrm{PGE}_{2}-d 4 \quad$ (9-oxo-11 $\alpha, 15 \mathrm{~S}$ dihydroxy-prosta-5Z,13E-dien-1-oic-3,3,4,4- $d 4$ acid); and $\mathrm{PGE}_{2}$-1-glyceryl ester- $d 5$ (9-oxo-11 $\alpha, 15 \mathrm{~S}$-dihydroxy-prosta-5Z,13E-dien-1-oic acid,1-glyceryl esterd5) were obtained from Cayman Chemicals Europe (Ann Arbor, MI, USA). MH-d6 (2-(4-methoxy-3-prop-2enylphenyl $(d)$ )-4-prop-2-enylphenol $(d)$ ). The structures of the $\mathrm{MH}$ derivatives were previously published in Schühly et al. [7] and Schuehly et al. [1]. The procedure of isolation and purification of $\mathrm{MH}$ and the synthesis of its derivatives was previously reported in [1,7]. All tubes used for assays (plastic and glass) were silanized.

\section{Animals}

All study involving animals are reported in accordance with the Swiss Federal guidelines. Female RjOrl: SWISS (60) 7 to 8 weeks old, provided by Janvier Labs (St Berthevin, France), were used for these experiments. The mice were housed in groups of five per cage in a selected pathogen-free unit under controlled 12-h light/12-h dark cycle, ambient temperature $21^{\circ} \mathrm{C} \pm 1^{\circ} \mathrm{C}$ humidity $40 \%$ to $50 \%$ with free access to standard rodent chow and water. The mice were acclimatized to the Animal House for at least 3 days before the experiment. 


\section{Radioligand displacement assays on $\mathrm{hCB}_{1}$ and $\mathrm{hCB}$ receptors}

Receptor binding experiments were performed with membrane preparations as previously reported [23]. Briefly, clean membranes expressing $h \mathrm{CB}_{1}$ or $h \mathrm{CB}_{2}$ were resuspended in binding buffer $(50 \mathrm{mM}$ Tris- $\mathrm{HCl}, 2.5$ mM EDTA, $5 \mathrm{mM} \mathrm{MgCl}_{2}, 0.5 \mathrm{mg} \mathrm{mL}^{-1}$ fatty acid-free bovine serum albumin (BSA), $\mathrm{pH}$ 7.4) and incubated with vehicle or compounds and $0.5 \mathrm{nM}$ of $\left[{ }^{3} \mathrm{H}\right]$ $\mathrm{CP} 55,940$ for $2 \mathrm{~h}$ at $30^{\circ} \mathrm{C}$. Non-specific binding was determined in the presence of $10 \mu \mathrm{M}$ of WIN55,512. After incubation, membranes were filtered through a presoaked 96-well microplate bonded with GF/B filters under vacuum and washed twelve times with $150 \mu \mathrm{L}$ of ice-cold binding buffer. The radioactivity was measured and the results expressed as $\left[{ }^{3} \mathrm{H}\right] \mathrm{CP} 55,940$ binding.

\section{$\left[{ }^{35}\right.$ S]GTPyS assay}

Assays were performed as previously described [24]. Briefly, $5 \mu \mathrm{g}$ of clean membranes expressing $h \mathrm{CB} 2$ were diluted in binding buffer $(50 \mathrm{mM}$ Tris- $\mathrm{HCl}, 3 \mathrm{mM}$ $\mathrm{MgCl}_{2}, 0.2 \mathrm{mM}$ EGTA, and $100 \mathrm{mM} \mathrm{NaCl}$ at $\mathrm{pH} 7.4$ plus $0.5 \%$ fatty acid-free BSA) in the presence of $10 \mu \mathrm{M}$ of GDP and $0.1 \mathrm{nM}$ of $\left[{ }^{35} \mathrm{~S}\right] \mathrm{GTP} \gamma \mathrm{S}$. The mixture was kept on ice until the binding reaction was started by adding the vehicle or compounds. Non-specific binding was measured in the presence of $10 \mu \mathrm{M}$ of GTP $\gamma \mathrm{S}$. The tubes were incubated at $30^{\circ} \mathrm{C}$ for $90 \mathrm{~min}$. The reaction was stopped by rapid filtration through a 96-well microplate bonded with GF/B filters previously pre-soaked with washing buffer (50 $\mathrm{mM}$ of Tris- $\mathrm{HCl} \mathrm{pH} 7.4$ plus $0.1 \%$ fatty acid-free BSA). The filters were washed six times with $180 \mu \mathrm{L}$ of washing buffer under vacuum. Experiments were performed in the presence and after removal of constitutive activity of $\mathrm{CB}_{2}$ receptors. In the latter, membranes were obtained from cells treated overnight with $10 \mu \mathrm{M}$ of AM630 to shift the vast majority of the receptor population in the inactive state. After the incubation, cells were washed six times with $10 \mathrm{~mL}$ of culture medium for $10 \mathrm{~min}$ each. Finally, cells were detached and membranes prepared and used to perform $\left[{ }^{35} \mathrm{~S}\right] \mathrm{GTP} \gamma \mathrm{S}$ binding assays. Membrane obtained from mock-transfected $\mathrm{CHO}$ cells were used as negative control. Membranes derived from mouse spleen $(20 \mu \mathrm{g})$ and human promyelocytic leukemia HL60 cells (40 $\mu \mathrm{g})$ were used as sources of $\mathrm{CB}_{2}$ receptors expressed in native conditions. In order to reduce the basal $\left[{ }^{35} \mathrm{~S}\right] \mathrm{GTP} \gamma \mathrm{S}$ binding, the experiments were performed after 30-min pretreatment with adenosine deaminase $\left(5\right.$ units $\left.\mathrm{mL}^{-1}\right)$. The radioactivity was measured, and the results were expressed as $\left[{ }^{35} \mathrm{~S}\right] \mathrm{GTP \gamma S}$ binding.

\section{cAMP assay}

cAMP assays were performed in $\mathrm{CHO}-h \mathrm{CB} 2$ stably transfected with the pGloSensorTM 22-F plasmid
(Promega, Madison, WI, USA) as previously described [22]. Briefly, cells were seeded in 96-well plate and kept in an equilibration medium (GloSensor ${ }^{\mathrm{TM}}$ cAMP reagent diluted in $5 \%$ of a $\mathrm{CO}_{2}$-independent medium plus $10 \%$ FBS) for $2 \mathrm{~h}$ at RT in the dark. Compounds or vehicle were diluted in an assay medium containing $1 \mu \mathrm{M}$ of forskolin and $250 \mu \mathrm{M}$ of 3-isobutyl-1-methylxanthine (IBMX). Chemiluminescence was recorded after $20 \mathrm{~min}$. Non-specific signal was determined in cells with only IBMX. Experiments were performed in the presence and after removal of the constitutive activity of the receptors following the same procedure described above. Results were normalized by subtracting the residual cAMP production and expressed amount of cAMP formed.

\section{$\beta$-arrestin assay}

The PathHunter ${ }^{\ominus} \beta$-arrestin cells (CHO-K1-HOMSACNR2) were gently donated by DiscoverX (via Hoffman La-Roche Ltd, Basel, Switzerland) and cultured in an F12 medium containing 10\% FBS, $200 \mu \mathrm{g} \mathrm{mL}^{-1}$ hygromycin and $800 \mu \mathrm{g} \mathrm{mL}^{-1}$ geneticin. For the experiments, $2 \times$ $10^{4}$ cells were seeded in 96-well plate and left overnight in the incubator. The day after, vehicle or compounds were diluted in $40 \mu \mathrm{L}$ of a $\mathrm{CO}_{2}$-independent medium plus $10 \%$ FBS. The mixture was added to the cells and incubated for $90 \mathrm{~min}$ at $37^{\circ} \mathrm{C}$. Chemiluminescence was detected using the PathHunter ${ }^{\oplus}$ detection system (DiscoveRx Corporation, Fremont, CA, USA) according to the instruction protocol. Background levels were subtracted and the results expressed as $\beta$-arrestin recruitment.

\section{COX-2 inhibition assay in vitro}

The experiments were performed as previously described [22]. Briefly, the inhibition of recombinant $h \mathrm{COX}-2$ was assessed using a COX fluorescent inhibitor screening assay kit from Cayman Chemicals Europe. Tested compounds or vehicle were pre-incubated with COX-FIS assay buffer (Tris-HCl $100 \mathrm{mM}, \mathrm{pH} 8$ ), $1 \mu \mathrm{M}$ of COX-FIS heme $h$ COX-2 FIS assay agent, and $30 \mu \mathrm{M}$ of ADHP (10-acetyl-3,7-dihydroxyphenoxazine) fluorometric substrate for $15 \mathrm{~min}$ at RT. The reaction was started by adding arachidonic acid, AEA, or 2-AG (10 $\mu \mathrm{M})$. Fluorescence intensity was measured $(535 / 580 \mathrm{~nm})$ after $5 \mathrm{~min}$ of incubation. The results were expressed as $h$ COX-2 activity.

\section{LC-MS/MS quantification of ECs and PGs in RAW264.7 cells}

In case of experiments with homogenates, cells were seeded in T75- $\mathrm{cm}^{2}$ flask and stimulated with LPS (1 $\mu \mathrm{g}$ $\mathrm{mL}^{-1}$ ) for $12 \mathrm{~h}$ at $37^{\circ} \mathrm{C}$. After incubation, cells were homogenized in assay buffer (Tris- $\mathrm{HCl} 10 \mathrm{mM}, \mathrm{pH} 8$ ) and $900 \mu \mathrm{g}$ of total protein were used to perform the COX-2 assay. When using intact cells, $0.5 \times 10^{6}$ cells were seeded in a 24-well plate and challenged with LPS (1 $\mu \mathrm{g}$ 
$\mathrm{mL}^{-1}$ ) for $12 \mathrm{~h}$ at $37^{\circ} \mathrm{C}$. The medium was discarded and replaced by a medium containing vehicle or compounds. After $30 \mathrm{~min}$ of incubation at $37^{\circ} \mathrm{C}, 2$-AG $(10 \mu \mathrm{M})$ was added and plates were incubated for an additional 30 min at $37^{\circ} \mathrm{C}$. Further experiments were carried out without adding 2-AG but stimulating its cellular biosynthesis. In this setting, RAW264.7 cells were treated for 8 $\mathrm{h}$ with LPS $\left(1 \mu \mathrm{g} \mathrm{mL} \mathrm{L}^{-1}\right)$, ATP $(1 \mathrm{mM})$, and thapsigargin $(2 \mu \mathrm{M})$ in the presence of vehicle or compounds. In both experimental conditions, after the incubation, cells were detached, transferred into a chloroform:methanol mixture (2:1) containing the internal standards (ISs), and then, phosphate buffered saline (PBS) was added to the final ratio of 6:3:1.5 (chloroform:methanol:PBS). The suspension was vortexed, sonicated, and centrifuged for $5 \mathrm{~min}$ at $800 \mathrm{~g}$ at $4^{\circ} \mathrm{C}$. The organic phase was recovered and dried under nitrogen. The quantification of AA, 2AG, $\mathrm{PGE}_{2}$, and $\mathrm{PGE}_{2} \mathrm{GE}$ was performed using LC-MS/ MS. The multiple reaction monitoring (MRM) parameters (precursor ion/product ion, declustering potential, collision energy) used in the survey and the respective IS are detailed in Gachet et al. [25] for all analytes except for: $\mathrm{MH}(\mathrm{Q}): 279 / 264 \mathrm{~m} / \mathrm{z},-70 \mathrm{eV},-23 \mathrm{eV}$ and (q): 279/248 $\mathrm{m} / \mathrm{z},-70 \mathrm{eV},-40 \mathrm{eV} ; \mathrm{MH}-d 6: 285 / 279 \mathrm{~m} / \mathrm{z},-82 \mathrm{eV},-24$ eV; PGE ${ }_{2} \mathrm{GE}(\mathrm{Q}): 444 / 409 \mathrm{~m} / \mathrm{z}, 40 \mathrm{eV}, 13 \mathrm{eV}$ and (q): 444/ $373 \mathrm{~m} / \mathrm{z}, 40 \mathrm{eV}, 19 \mathrm{eV}$; and PGE $\mathrm{PE}_{2}$-d5: 449/396 m/z, 43 $\mathrm{eV}, 17 \mathrm{eV}$. The quantification was based on the area ratio of analytical standard/IS.

\section{LC-MS/MS quantification of ECs and PGs in vivo}

Swiss albino mice (females, 8 weeks old) were injected intraperitoneally (i.p.) with vehicle or $\mathrm{MH}$ at different doses $\left(3,10\right.$, and $20 \mathrm{mg} \mathrm{kg}^{-1}$ ). Female mice were used for ethical reasons because they were less susceptible for neuroinflammatory damage in this model. After $1 \mathrm{~h}$, the animals (6 to 14 animals per group) were injected i.p. with LPS $\left(2.5 \mathrm{mg} \mathrm{kg}^{-1}\right)$ and kept in the dark for an additional $6 \mathrm{~h}$. After anesthetization, mice were perfused with PBS and the brains were collected. Lipid extraction was performed as recently described (Gachet et al. [25]). In brief, half brain was homogenized on a BeadBeater (Mini-BeadBeater-24, BioSpec, Bartlesville, OK USA) using Chrome-Steel Beats (2.3 $\mathrm{mm}$ dia., BioSpec) in the presence of ice-cold chloroform:methanol (2:1) for 1 $\min \left(3,450\right.$ strokes $\left.\mathrm{min}^{-1}\right)$ at $4^{\circ} \mathrm{C}$. Homogenates were added with PBS (containing ISs) to the final ratio of 6:3:1.5 (chloroform:methanol:PBS). The suspension was vortexed, sonicated, and centrifuged for $5 \mathrm{~min}$ at $800 \mathrm{~g}$ at $4^{\circ} \mathrm{C}$. The organic phase was recovered and dried under nitrogen. Subsequently, the samples were reconstituted in ethanol and after the addition of water and $\mathrm{pH}$ adjustment $(\mathrm{pH}=3)$, an aliquot was extracted using C-18Sep-Pak cartridge (Waters AG, Zug, Switzerland). Cartridges were washed with $10 \%$ ethanol and eluted with acetonitrile (ACN)/ethyl acetate (1:1). The eluates were collected and evaporated to dryness under nitrogen. The samples were reconstituted in ACN, centrifuged for 5 min at $16,100 \mathrm{~g}$ at $4^{\circ} \mathrm{C}$, and measured by LC-MS/MS in negative and positive modes. The quantification was based on the area ratio of analytical standard/IS.

\section{$\left[{ }^{3} \mathrm{H}\right] \mathrm{AEA}$ and $\left[{ }^{3} \mathrm{H}\right] 2-\mathrm{AG}$ hydrolysis assay}

The experiments were performed as previously described [23]. Briefly, vehicle or compounds were preincubated for $30 \mathrm{~min}$ at $37^{\circ} \mathrm{C}$ with $200 \mu \mathrm{g}$ of pig brain homogenate for FAAH and MAGL and $100 \mu \mathrm{g}$ of BV-2 cell homogenate for ABHDs in assay buffer $(10 \mathrm{mM}$ Tris- $\mathrm{HCl}, 1 \mathrm{mM}$ EDTA, pH 7.6 plus $0.1 \%$ fatty acid-free BSA). To measure FAAH activity, a mixture of AEA/ $\left[{ }^{3} \mathrm{H}\right]$ AEA was added to the homogenate (final concentration of $1 \mu \mathrm{M}$ ) and incubated for $15 \mathrm{~min}$ at $37^{\circ} \mathrm{C}$. After incubation, tubes were added with chloroform:methanol (1:1), vortexed, and centrifuged at 10,000 rpm for 10 min at $4^{\circ} \mathrm{C}$. To measure MAGL/ABHDs activity, AEA and $\left[{ }^{3} \mathrm{H}\right] \mathrm{AEA}$ were replaced by 2-oleoylglycerol (2-OG) and $\left.{ }^{3} \mathrm{H}\right] 2-\mathrm{OG}$, respectively. The radioactivity associated to the $\left[{ }^{3} \mathrm{H}\right]$ ethanolamine (or $\left[{ }^{3} \mathrm{H}\right]$ glycerol) formation was measured in the aqueous phase. The results were expressed as enzymatic activity.

\section{$\left[{ }^{3}\right.$ H]AEA uptake into U937 cells}

The experiments were performed as previously described [23]. Briefly, $10^{6}$ of U937 cells were suspended in $0.5 \mathrm{~mL}$ of PBS and pre-incubated with vehicle or compounds for $30 \mathrm{~min}$ at $37^{\circ} \mathrm{C}$. Successively, cells were added with a mixture of AEA/ $\left[{ }^{3} \mathrm{H}\right] \mathrm{AEA}$ (final concentration of $100 \mathrm{nM}$ ) and incubated for $5 \mathrm{~min}$ at $37^{\circ} \mathrm{C}$. The uptake process was stopped by rapid centrifugation at $800 \mathrm{~g}$ for $5 \mathrm{~min}$ at $4^{\circ} \mathrm{C}$. The supernatant was discarded and the pellet washed with ice-cold PBS plus $1 \%$ of fatty acid-free BSA. Cell pellets were resuspended in PBS and extracted with chloroform:methanol (1:1). The organic phase was collected and the radioactivity measured. The results were expressed as $\left[{ }^{3} \mathrm{H}\right] \mathrm{AEA}$ uptake. In case of U937 cell-derived macrophages, U937 cells were treated for $48 \mathrm{~h}$ with $2 \mathrm{ng} \mathrm{mL} \mathrm{m}^{-1}$ of phorbol 12-myristate 13acetate (PMA) and the uptake experiments were performed as described above.

\section{Data analysis}

Data were collected from at least three independent experiments each performed in triplicate. Results are expressed as mean values and standard deviation (SD). The $\left[{ }^{35} \mathrm{~S}\right] \mathrm{GTP} \gamma \mathrm{S}$ assays performed using $\mathrm{CHO}-\mathrm{hCB}_{2}$ membranes were repeated five times, and the error was expressed as standard error of the mean (SEM). The statistical significance difference among groups was determined by Student's $t$ test (paired, two-tailed $t$ test) or 
one-way ANOVA followed by Bonferroni's post-test. Statistical differences between treated and control groups were considered as significant if $P \leq 0.05$. GraphPad 5.0 software was used to fit the concentrationdependent curves and for the statistical analysis.

\section{Results}

First, we confirmed that $\mathrm{MH}$ (Figure 1) selectively binds to $\mathrm{CB}_{2}$ receptors with a $K_{\mathrm{i}}$ value of 188.5 (131.7 to 269.4) $\mathrm{nM}$ over 2.4 (1.9 to 2.9) $\mu \mathrm{M}$ for $\mathrm{CB}_{1}$ receptors (Table 1). MH induced a concentration-dependent increase of $\left[{ }^{35} \mathrm{~S}\right] \mathrm{GTP} \gamma \mathrm{S}$ binding with an $\mathrm{EC}_{50}$ value of 285.7 (125.6 to 647.2) $\mathrm{nM}$ and a maximal binding of $185.7 \%$ (167.1 to 204.3) (Figure 2A). In the same assay, the positive control 2-AG-induced $\left[{ }^{35} \mathrm{~S}\right] \mathrm{GTP} \mathrm{S}$ binding with an $\mathrm{EC}_{50}$ value of 74.0 (28.4 to 192.9$) \mathrm{nM}$, reaching $252.8 \%$ (210.2 to 295.4) of maximal response. Statistical analyses confirmed that $\mathrm{MH}$ induced a lower maximal G-protein recruitment compared to the endogenous full agonist 2-AG, thus suggesting partial agonism. Partial agonists are versatile ligands which can behave as agonists or antagonists depending on the conditions [26]. In Figure 2B, the incubation of fixed concentrations of $\mathrm{MH}$ with increasing concentrations of 2-AG exemplifies these opposite pharmacological behaviors. While $\mathrm{MH}$ induced G-protein recruitment at inactive 2-AG concentrations, it reduced the effects induced by high concentrations of the full agonist. We also investigated the behavior of $\mathrm{MH}$ using human promyelocytic leukemia HL60 cells [27] and mouse spleen [28] which both endogenously express $\mathrm{CB}_{2}$ receptors. As reported in Figure 2C,D, 2-AG, CP55,940, and $\mathrm{MH}$ behaved as agonists by increasing the $\left[{ }^{35} \mathrm{~S}\right] \mathrm{GTP} \gamma \mathrm{S}$ binding compared to vehicle, while SR144528 and AM630
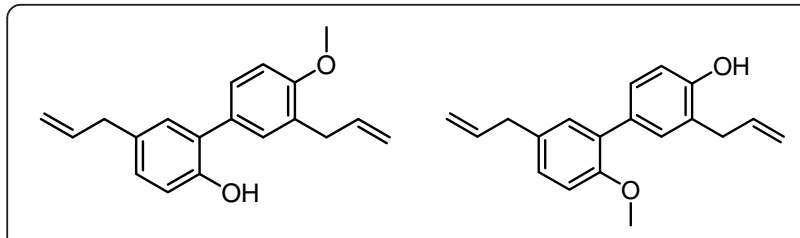

4'-O-methylhonokiol (MH)

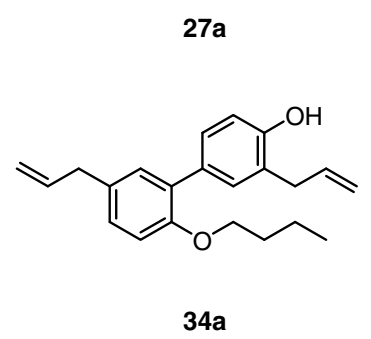

Figure 1 Chemical structures of $4^{\prime}-0$-methylhonokiol (-4'-methoxy-5,3'di-(2-propenyl)-biphenyl-2-ol), 27a (2-methoxy-5,3'-di-(2-propenyl)biphenyl-4'-ol), 32 (5,5'-di-sec-butyl- biphenyl-2,2'-diol) and 34a (2-butyloxy-5,3'-di-(2-propenyl)- biphenyl-4'-ol). reduced G-protein recruitment, thus behaving as inverse agonists. In agreement with the results obtained in $\mathrm{CHO}-$ $h \mathrm{CB}_{2}$ membranes, $\mathrm{MH}$ induced a sub-maximal binding of $\left[{ }^{35} \mathrm{~S}\right] \mathrm{GTP} \gamma \mathrm{S}$ compared with the full agonists CP55,940 and 2-AG, in both HL60- and spleen-derived membranes, thus confirming its partial agonist behavior. In addition, we also tested 2-AG, CP55,940, and MH effects using membranes derived from mock-transfected $\mathrm{CHO}$ cells. All ligands showed no change of the basal level of $\left[{ }^{35} \mathrm{~S}\right] \mathrm{GTP} \gamma \mathrm{S}$ binding (Additional file 1: Figure S1). Altogether, these data indicate that $\mathrm{MH}$ behaves as an agonist at $\mathrm{CB}_{2}$ receptors in both overexpressing and native conditions. We next characterized the effects of $\mathrm{MH}$ on the $\mathrm{CB}_{2}$ receptor-mediated inhibition of forskolin-induced cAMP production. As shown in Figure 2E, increasing concentrations of $\mathrm{MH}$ inhibited cAMP formation with an $\mathrm{IC}_{50}$ value of 674 (481 to 944) nM. In this assay, in contrast to previous results [1], $\mathrm{MH}$ behaved as a full agonist producing the same maximal inhibition as the full agonist 2-AG (data not shown). $\mathrm{CB}_{2}$ receptors are known to possess a high intrinsic constitutive activity. Therefore, compounds that act as 'protean agonists' can behave differently depending on the proportion of constitutively activated receptors. 'Protean agonists' bind to the receptor and stabilize an active conformation that is capable of initiating signal where there is none (inactive state of the receptor), but they trigger an active state of the receptor that is less efficacious than the naturally occurring, spontaneously formed constitutive active state [29]. Thus, 'protean agonists' can behave as an agonist or inverse agonist depending on the active state of the receptor. This phenomenon has been accurately investigated over the past few years, and it was found that by pre-treating $C_{2}$ receptors overnight with the inverse agonist AM630, most of the receptors shift towards the inactive state, thus abolishing the constitutive activity [30]. For example, an inverse agonist becomes a silent antagonist [30] and a protean agonist can switch from an inverse agonist to an agonist or antagonist [30,31]. We have validated our assay system by showing that after removing the constitutive activity, AM630 and SR144528 switched from an inverse agonist to a silent antagonist, while CP55,940 did not change its behavior (Additional file 1: Figure S2) in agreement with the literature [30,32]. As shown in Figure $2 \mathrm{E}, \mathrm{MH}$ acted as a full agonist in both conditions, suggesting that in our assay, the level of constitutive activity of $\mathrm{CB}_{2}$ receptors did not qualitatively affect the pharmacological behavior of $\mathrm{MH}$. We also investigated the effect of $\mathrm{MH}$ on $\beta$-arrestin recruitment. In Figure 2F, it is clearly shown that similarly to $\left[{ }^{35} \mathrm{~S}\right] \mathrm{GTP} \gamma \mathrm{S}$ results, the compound induced a sub-maximal effect compared to $\mathrm{CP} 55,940$, therefore behaving as a partial agonist. $\mathrm{MH}$ has been shown to inhibit the COX-2-mediated AA oxygenation [7]. However, COX-2 is responsible also for the oxygenation of AEA and 2-AG leading to the formation of 
Table 1 Summary of the pharmacological effects exerted by $\mathrm{MH}, 27 \mathrm{a}, 32$, and $34 \mathrm{a}$

\begin{tabular}{|c|c|c|c|c|c|c|c|c|c|c|c|c|}
\hline \multicolumn{13}{|c|}{$\mathrm{IC}_{50}$ or $K_{\mathrm{i}}$ values (mean value $\pm \mathrm{SD}, \mu \mathrm{M}$ ) } \\
\hline & \multicolumn{2}{|l|}{$h \operatorname{COX}-2$} & \multicolumn{2}{|c|}{ RAW264.7 Intact cells } & \multicolumn{3}{|c|}{ CHO membranes } & \multirow{2}{*}{$\begin{array}{l}\text { CHO cells } \\
h \text { CB2 cAMP }\end{array}$} & \multicolumn{2}{|c|}{ Pig brain homog. } & \multirow{2}{*}{$\begin{array}{l}\text { BV-2 homog. } \\
\text { ABHDs }\end{array}$} & \multirow{2}{*}{$\begin{array}{l}\text { U937 cells } \\
\text { AEA uptake }\end{array}$} \\
\hline & $\overline{\mathrm{AA}}$ & 2-AG & $\overline{A A}$ & 2-AG & $h \mathrm{CB}_{1}$ & $h \mathrm{CB}_{2}$ & $h \mathrm{CB} 2\left[{ }^{35} \mathrm{~S}\right] \mathrm{GTP} \gamma \mathrm{S}$ & & FAAH & MAGL & & \\
\hline$\overline{\mathrm{MH}}$ & $0.58 \pm 0.08$ & ${ }^{* *} 0.15 \pm 0.09$ & $1.56 \pm 0.12$ & ${ }^{* *} 0.28 \pm 0.09$ & $2.4 \pm 0.6$ & $0.19 \pm 0.12$ & $0.20 \pm 0.10$ & $0.67 \pm 0.07$ & $>10$ & $>10$ & $>10$ & $6.5 \pm 1.2$ \\
\hline $27 a$ & $1.21 \pm 0.08$ & ${ }^{* *} 0.42 \pm 0.09$ & $0.98 \pm 0.08$ & ${ }^{* *} 0.28 \pm 0.11$ & $0.79 \pm 0.10$ & $0.11 \pm 0.09$ & $0.18 \pm 0.09$ & $0.71 \pm 0.09$ & $>10$ & $>10$ & $>10$ & $>10$ \\
\hline 32 & $10.2 \pm 0.12$ & ${ }^{* *} 0.63 \pm 0.05$ & $2.8 \pm 0.22$ & ${ }^{* *} 0.21 \pm 0.14$ & $>10$ & $>10$ & n.d. & n.d. & $>10$ & $>10$ & $>10$ & $6.3 \pm 1.6$ \\
\hline $34 a$ & $4.31 \pm 0.10$ & ${ }^{*} 1.29 \pm 0.07$ & $>30$ & ${ }^{* *} 1.57 \pm 0.13$ & $1.12 \pm 0.15$ & $0.35 \pm 0.11$ & $1.82 \pm 0.14$ & $1.52 \pm 0.13$ & $>10$ & $>10$ & $>10$ & $>10$ \\
\hline DuP-697 & $0.061 \pm 0.005$ & $0.07 \pm 0.01$ & $0.004 \pm 0.004$ & $0.005 \pm 0.006$ & n.d. & n.d. & n.d. & n.d. & n.d. & n.d. & n.d. & n.d. \\
\hline
\end{tabular}

The data are expressed as mean $\pm S D$ of at least three independent experiments each performed in triplicates. Binding affinity to $C B_{1}$ and $C B_{2}$ receptors is expressed as $K_{i}$ value while modulation of $C B_{2}$ receptor

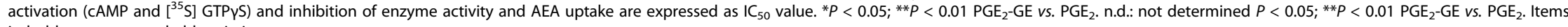
in bold are compound abbreviations. 


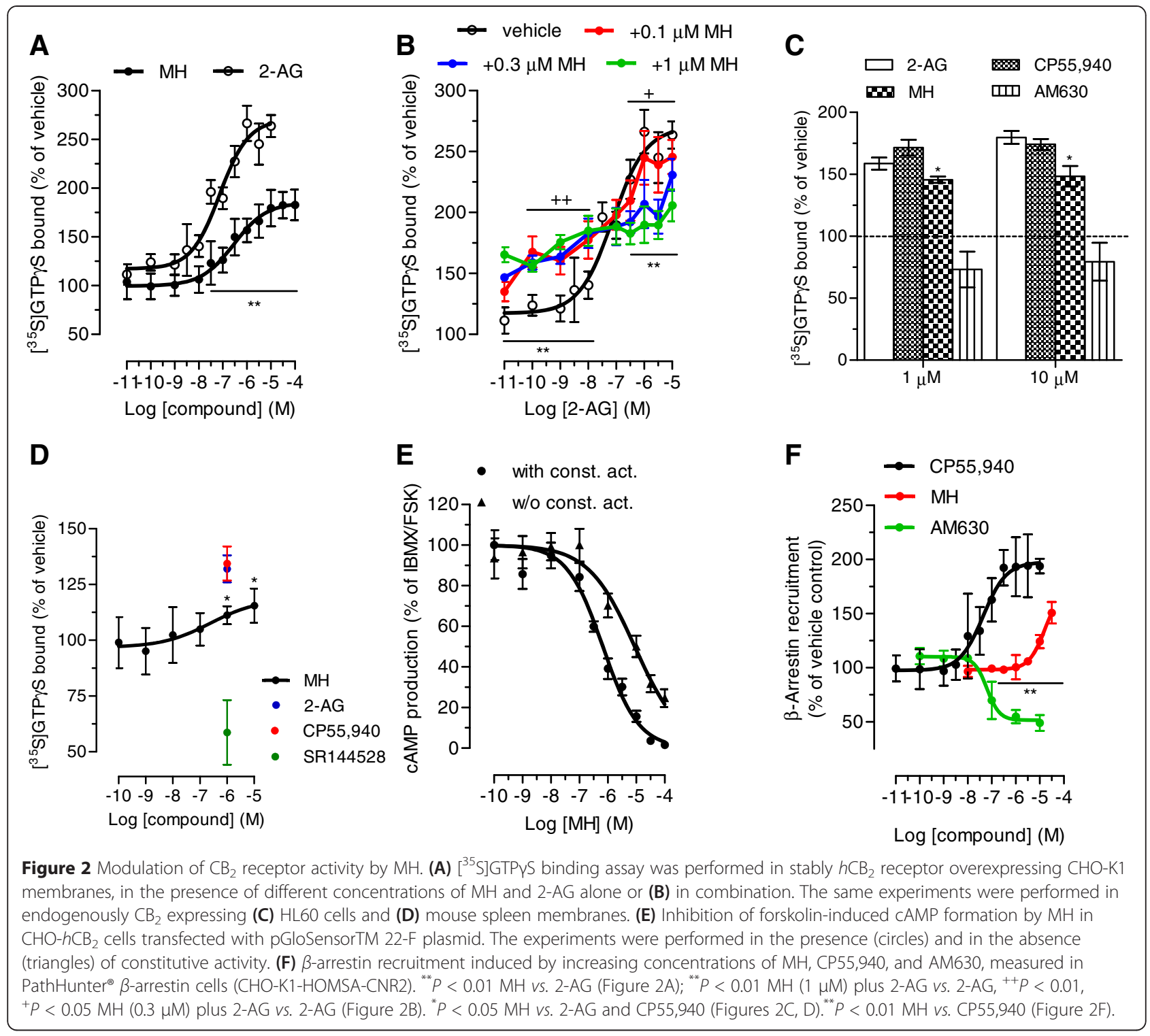

PG-EAs and PG-GEs, respectively [10,14,21,33]. Therefore, we next studied whether $\mathrm{MH}$ selectively inhibits the COX-2-mediated oxygenation of ECs. In Figure 3A, the concentration-dependent inhibition of purified $h C O X-2$ is shown using $10 \mu \mathrm{M}$ of AEA, 2-AG, and AA as substrates. Noteworthy, $\mathrm{MH}$ inhibited the oxygenation of ECs with $\mathrm{IC}_{50}$ values of 158 (123 to 204) nM and 156 (129 to 189) nM for AEA and 2-AG, respectively, while it blocked AA oxygenation with an $\mathrm{IC}_{50}$ value of 588 (499 to 693) nM (Table 1). We then confirmed the apparent SSI of COX-2 in LPS-stimulated RAW264.7 cells by using cell homogenates and intact cells. We quantified the amount of $\mathrm{PGE}_{2}$ and $\mathrm{PGE}_{2}$-GE formation by LC-MS/MS analysis after incubation for $30 \mathrm{~min}$ with $10 \mu \mathrm{M}$ of 2-AG. As shown in Figure $3 \mathrm{~B}, \mathrm{C}, \mathrm{MH}$ inhibited $\mathrm{PGE}_{2}-\mathrm{GE}$ formation with a higher potency ( $\mathrm{IC}_{50}$ value: 301 (257 to 490$) \mathrm{nM}$ ) compared to $\mathrm{PGE}_{2}\left(\mathrm{IC}_{50}\right.$ value: $1.21(0.792$ to 1.81$\left.) \mu \mathrm{M}\right)$ in both systems. The mass chromatograms of $\mathrm{PGE}_{2}$ and $\mathrm{PGE}_{2}-\mathrm{GE}$ formed upon incubation of LPS-stimulated RAW264.7 cell homogenates as well as from intact cells incubated with 2-AG are shown in Figure 4. The LC-MS/MS method was validated by measuring the nonselective COX-2 inhibitor DuP-697 which showed the same potency in inhibiting the oxygenation of ECs and AA (Figure 3A,B,C,D). RAW264.7 cells can be stimulated to produce significant levels of 2-AG by raising intracellular levels of $\left[\mathrm{Ca}^{2+}\right]$. Cells were stimulated for $8 \mathrm{~h}$ with LPS, ATP, and thapsigargin in the presence of vehicle or different concentrations of $\mathrm{MH}$. Figure 5A, B shows the concentration-dependent inhibition of $\mathrm{PGE}_{2}$ and $\mathrm{PGE}_{2}$ - 


\section{RAW264.7}

A

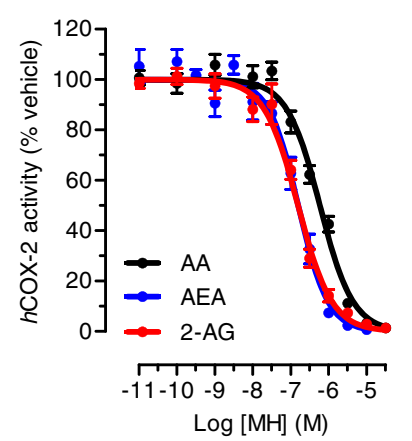

B

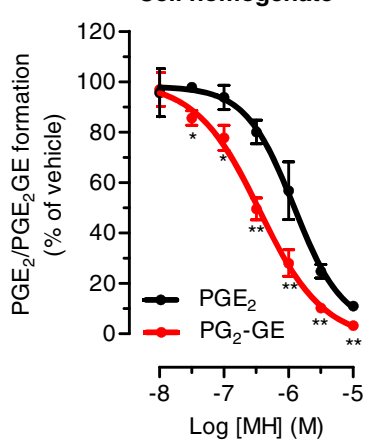

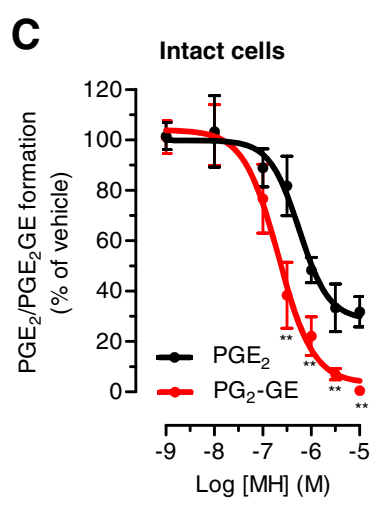

Figure 3 Dose-dependent COX-2 inhibition induced by MH in different biological matrices. (A) MH-mediated inhibition of $h$ COX-2 using $10 \mu \mathrm{M}$ of AA (black), AEA (blue), and 2-AG (red) as substrates. MH-mediated inhibition of PGE 2 and PGE 2 -GE formation in (B) RAW264.7 cell homogenate and $(\mathbf{C})$ intact cells after $12 \mathrm{~h}$ of incubation with LPS $\left(1 \mathrm{mg} \mathrm{mL}^{-1}\right)$. Homogenates and intact cells were incubated for 30 min with $10 \mu \mathrm{M}$ of 2-AG after the pre-treatment (30 min) with different concentrations of $\mathrm{MH}$ or vehicle. ${ }^{*} P<0.05,{ }^{* *} P<0.01 \mathrm{PGE}_{2} \mathrm{Vs} . \mathrm{PGE}_{2}-\mathrm{GE}$.

A

RAW264.7 cell homogenate

2-AG oxygenation

AA oxygenation

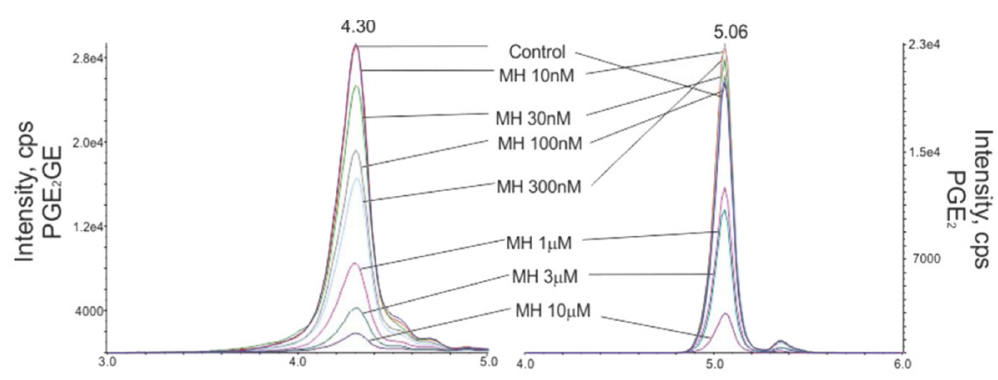

B

RAW264.7 intact cells

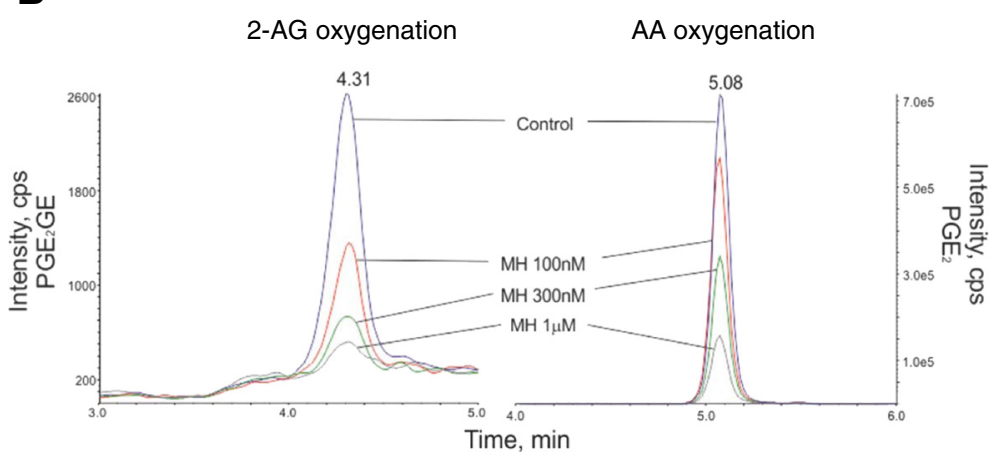

Figure $4 \mathrm{MS}$ chromatograms of $\mathrm{PGE}_{2}$ and $\mathrm{PGE} \mathrm{E}_{2}-\mathrm{GE}$ measured in different biological matrices. Quantification of $P G E_{2}$ and $P G E_{2}-G E$ formation measured after incubation of (A) RAW264.7 cell homogenate and (B) intact cells with $10 \mu \mathrm{M}$ of AA or 2-AG in the presence of different concentrations of $\mathrm{MH}$ or vehicle. Homogenates and cells were treated for $12 \mathrm{~h}$ with LPS (1 $\left.\mathrm{mg} \mathrm{mL}^{-1}\right)$ followed by 30 -min incubation with $10 \mu \mathrm{M}$ of 2-AG after the pre-treatment (30 min) with different concentrations of $\mathrm{MH}$ or vehicle. 


\section{A}

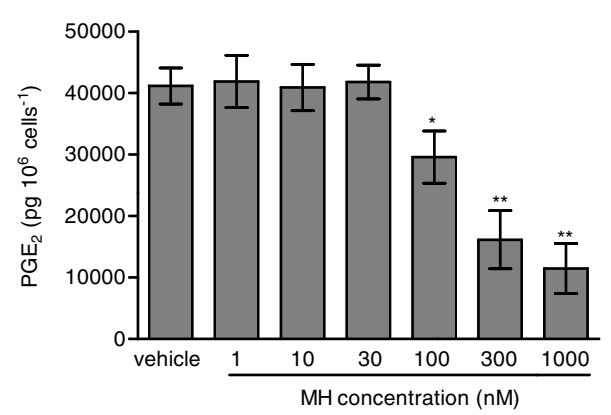

B

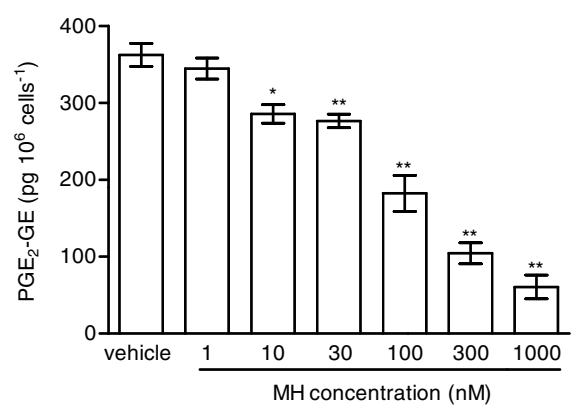

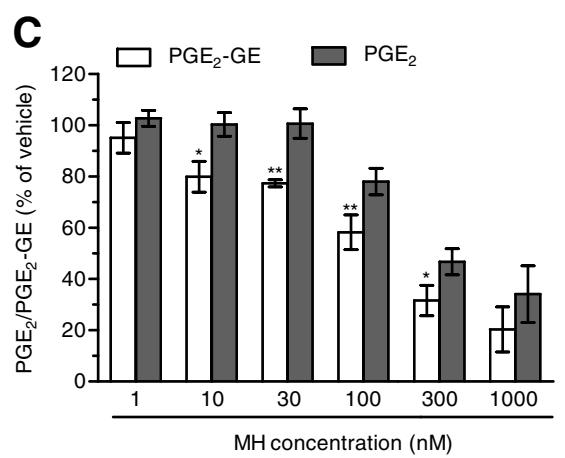

Figure $5 \mathrm{MH}$-mediated inhibition of $\mathrm{PGE}_{2}$ and $\mathrm{PGE}_{2}$-GE formation in RAW264.7 cells without external addition of 2-AG. Concentration-dependent inhibition of (A) $\mathrm{PGE}_{2}$ and (B) $\mathrm{PGE}_{2}$-GE formation (picogram per million of cell) in RAW264.7 intact cells previously stimulated with LPS (1 $\mathrm{mg} \mathrm{mL}^{-1}$ ) ATP $(1 \mathrm{mM})$ and thapsigargin $(2 \mu \mathrm{M})$ for $8 \mathrm{~h}$. (C) PGE 2 and $\mathrm{PGE}_{2}$-GE formation inhibition upon different concentrations of $\mathrm{MH}$ (expressed as \% of vehicle-treated cells). ${ }^{*} P<0.05,{ }^{* *} P<0.01 \mathrm{MH}$ treated samples vs. vehicle for panels (A) and (B); ${ }^{*} P<0.05,{ }^{* *} P<0.01 \mathrm{PGE}_{2}-\mathrm{GE}$ vs. PGE $\mathrm{E}_{2}$ for panel (C).

GE formation by $\mathrm{MH}$. Intriguingly, already at low concentrations (10 to $30 \mathrm{nM}$ ), $\mathrm{MH}$ led to $20 \%$ to $25 \%$ inhibition of 2-AG oxygenation while AA oxygenation was not affected. At high concentrations (100 to $300 \mathrm{nM}$ ), $\mathrm{MH}$ inhibited the formation of both prostaglandin types but with more pronounced effects on $\mathrm{PGE}_{2}$-GE. At $1 \mu \mathrm{M}, \mathrm{MH}$ almost fully inhibited COX-2-mediated oxygenation of AA and 2-AG lacking the substrate specificity (Figure 5C). Since the absolute amount of $\mathrm{PGE}_{2}$ formed was about 100-times higher than $\mathrm{PGE}_{2}-\mathrm{GE}$, we wanted to exclude a potential bias in the sensitivity of the system due to different amounts of the initial substrates (AA and 2-AG). Therefore, we tested the effects of DuP-697, and the results confirmed that this non-selective inhibitor potently blocked the formation of $\mathrm{PGE}_{2}$ and $\mathrm{PGE}_{2}$-GE with the same potency (Additional file 1: Figure S3E). To assess the relevance of COX-2 SSI in vivo, we evaluated the effects of $\mathrm{MH}$ in LPS-challenged Swiss albino mice. Animals were injected intraperitoneally (i.p.) with vehicle or different concentrations of $\mathrm{MH}$ and after $1 \mathrm{~h}$, challenged for $6 \mathrm{~h}$ with LPS. Brain levels of AEA, 2-AG, AA, and $\mathrm{PGE}_{2}$, expressed as nmol (or pmol) $\mathrm{mg}^{-1}$ of tissue are shown in Figure 6A,B,C,D. Upon LPS injection, the amount of AA, 2-AG, and AEA did not significantly change, while $\mathrm{PGE}_{2}$ and corticosterone strongly increased (Figure 6E), as expected, and in agreement with the literature [34,35]. $\mathrm{MH}$ treatment did not affect the amount of AA and corticosterone at any concentration, while it slightly reduced the levels of $\mathrm{PGE}_{2}$ only at $20 \mathrm{mg} \mathrm{kg}^{-1}$. MH did not significantly affect AEA levels, while significantly increasing the amount of free $2-A G$ at 10 and $20 \mathrm{mg} \mathrm{kg}^{-1}$, with a tendency of increase also at the lowest dose tested (3 $\mathrm{mg} \mathrm{kg}^{-1}$ ). Since 2-AG levels are about 500 to 1,000 times higher than AEA levels in Swiss albino mice, and assuming that both ECs are equipotent substrates for COX-2, it is not unexpected to see this more pronounced effect (doubling the amount) of a SSI COX-2 inhibitor on 2-AG levels. $\mathrm{PGE}_{2}-\mathrm{EA}$ and $\mathrm{PGE}_{2}-\mathrm{GE}$ were below the limit of detection. Moreover, NA-GABA $(N$ arachidonoyl GABA) and other $N$-acylethanolamines were not significantly affected by $\mathrm{MH}$ (Additional file 1: Figure S4). These findings suggest that $\mathrm{MH}$ maintained the ability to specifically inhibit COX-2-mediated EC oxygenation in vivo without affecting the oxygenation of AA. Several publications have recently demonstrated in vitro and in vivo beneficial effects of $\mathrm{MH}$ in neurodegenerative disease models $[2,4,36]$. Nonetheless, the penetration of the compound across the blood-brain barrier has never been investigated. We therefore established an LC-MS/MS method to quantify $\mathrm{MH}$ in the 

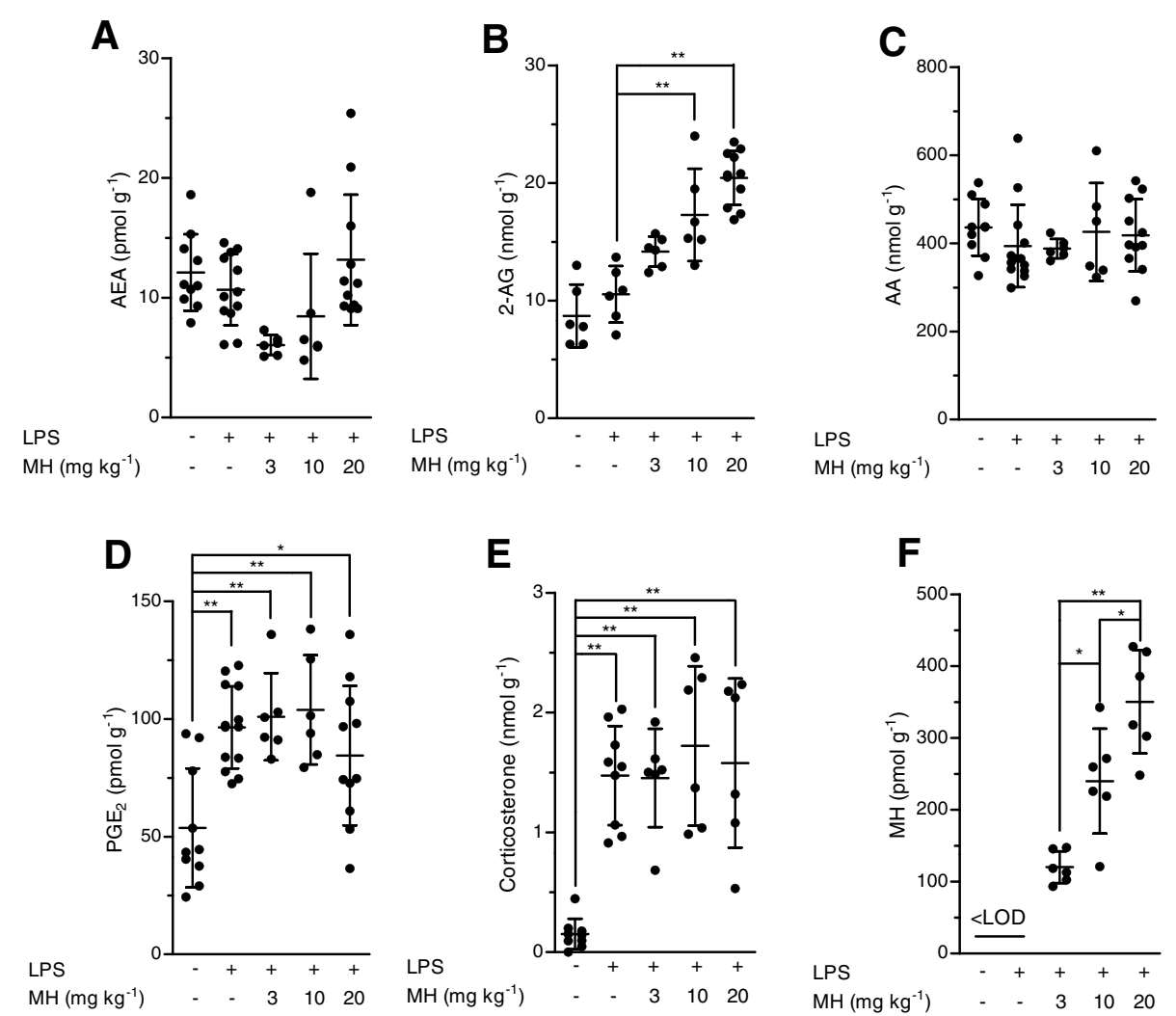

Figure 6 LC-MS/MS quantification of different analytes in mouse brain. (A) AEA, (B) 2-AG, (C) AA, (D) PGE 2 , and (E) corticosterone were quantified in the brains from mice (6 to 14 animals per group) challenged for $6 \mathrm{~h}$ with LPS (i.p., $2.5 \mathrm{mg} \mathrm{kg}^{-1}$, or saline), after $1 \mathrm{~h}$ of pre-treatment with MH (i.p., 3, 10, and $20 \mathrm{mg} \mathrm{kg}^{-1}$ ) or vehicle. (F) MH quantification in the brain of LPS-challenged mice. ${ }^{*} P<0.05,{ }^{* * *} P<0.01$ treated vs. not-treated

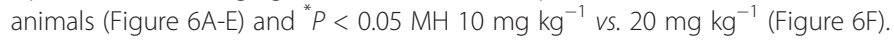

brain. Data show that after $7 \mathrm{~h}$ after the injection of 3 , 10 , and $20 \mathrm{mg} \mathrm{kg}^{-1}$, the brain contains 120.1 (93.6 to 147.5), 239.8 (121.1 to 342.3 ), and 350.2 (248.1 to 426.9 ) pmol g $\mathrm{g}^{-1}$ of $\mathrm{MH}$, respectively (Figure $6 \mathrm{~F}$ ). These results correlate with the significant increase of EC levels induced by 10 and $20 \mathrm{mg} \mathrm{kg}^{-1}$ of $\mathrm{MH}$, while only showing a tendency at $3 \mathrm{mg} \mathrm{kg}^{-1}$. An increase of 2-AG levels can also be achieved by inhibiting its hydrolysis. Therefore, we tested the effects of $\mathrm{MH}$ on all the major EC hydrolytic enzymes (FAAH, MAGL, ABHDs) confirming that it does neither affect AEA nor 2-AG hydrolysis (Table 1), while the positive controls URB597, JZL184, and WWL70/tetrahydrolipstatin (for FAAH, MAGL, and ABHDs, respectively) inhibited EC hydrolysis as in agreement with the literature (data not shown) [22]. The trafficking of ECs across plasma membranes is likely regulated by a putative EC membrane transporter (EMT), and several inhibitors prevent intracellular accumulation of AEA and 2-AG [37]. MH only weakly inhibited the cellular accumulation of $\left[{ }^{3} \mathrm{H}\right] \mathrm{AEA}$ in U937 cells with an $\mathrm{IC}_{50}$ value of 6.5 (4.7 to 9) $\mu \mathrm{M}$ (Table 1). A similar potency $\left(\mathrm{EC}_{50}\right.$ value of $2.7(1.1$ to 6.5$\left.) \mu \mathrm{M}\right)$ was observed using U937 cells differentiated into macrophages which lack the $\left[{ }^{3} \mathrm{H}\right]$ ethanolamine incorporation into phospholipids (as shown previously [37]), therefore ruling out potential effects on other targets indirectly related to the process of $\left[{ }^{3} \mathrm{H}\right]$ AEA uptake (Additional file 1: Figure S5). In the same system, the positive control UCM707 inhibited $\left[{ }^{3} \mathrm{H}\right]$ AEA uptake with an $\mathrm{IC}_{50}$ value of 1.6 (0.8 to 2.5) $\mu \mathrm{M}$ and 2.4 (1.2 to 3.6) $\mu \mathrm{M}$ in U937 cells and U937 cells differentiated into macrophages, respectively, in agreement with previous reports [23,37]. Thus, with nanomolar brain concentrations of $\mathrm{MH}$, the inhibition of EC trafficking is unlikely to contribute to raising 2-AG levels in vivo.

We tested a library of $40 \mathrm{MH}$, magnolol, and honokiol analogs for COX-2 SSI previously described $[1,7]$. Compounds which showed $>50 \%$ inhibition of 2-AG oxygenation at $2 \mu \mathrm{M}$ were selected for further investigations. As shown in Additional file 1: Figure S6A, B, from the whole library, only three molecules (27a, 32, and 34a, see Figure 1 for chemical structures) showed a stronger, selective inhibition of 2-AG oxygenation over AA. We characterized the effects of these three compounds in purified $h$ COX-2, RAW264.7 cell homogenates, and intact cells similarly to $\mathrm{MH}$. As shown in Figure 7, all compounds selectively inhibited 2-AG oxygenation with 


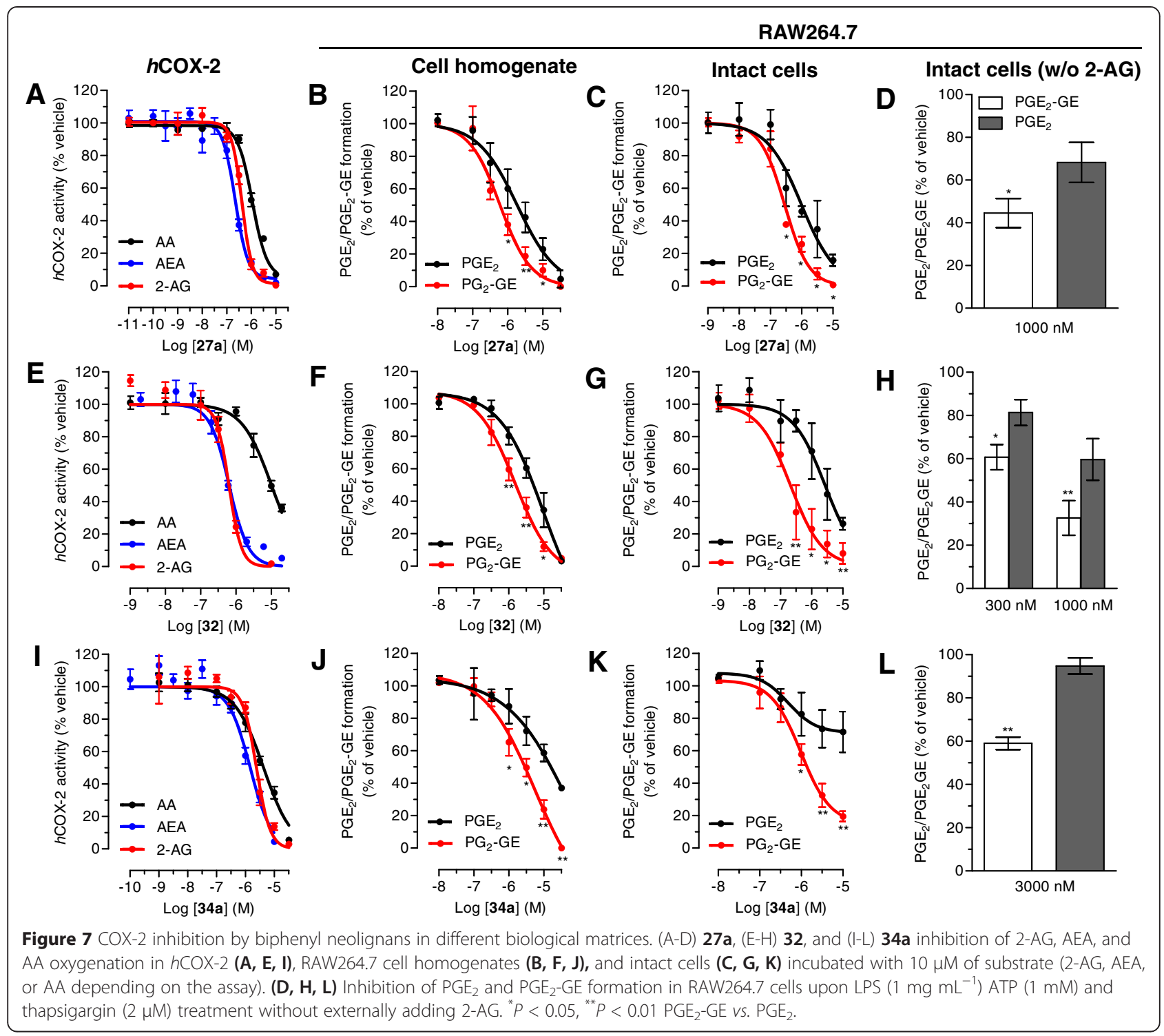

potencies ranging from $210 \mathrm{nM}(32)$ to $1.57 \mu \mathrm{M}$ in living cells (34a). Compounds 32 and 34a showed the greatest selectivity for 2-AG oxygenation (10/15-fold more potent than AA oxygenation (Table 1)). At $10 \mu \mathrm{M}, 32$ did not show any relevant binding at both $\mathrm{CB}$ receptor subtypes, while $27 \mathbf{a}$ and $34 \mathbf{a}$ showed selective $\mathrm{CB}_{2}$ binding (Table 1). Next, we characterized the functional effects of both ligands by assessing G-protein and $\beta$-arrestin recruitment and cAMP formation. Compound 27a, which was previously reported to be an inverse agonist [1], in our settings like $\mathrm{MH}$ behaved as a partial agonist in the $\left[{ }^{35} \mathrm{~S}\right] \mathrm{GTP} \gamma \mathrm{S}$ assay (Figure 8A), exhibiting full agonism at inhibiting the forskolin-induced cAMP production (Figure $8 \mathrm{~B}$ ) and sub-maximal recruitment of $\beta$-arrestin (Figure $8 \mathrm{C}$ ). However, compound $34 \mathrm{a}$ reduced $\left[{ }^{35} \mathrm{~S}\right] \mathrm{GTP} \gamma \mathrm{S}$ binding and increased cAMP formation, thus behaving as an inverse agonist (Figure 8A, B). Interestingly, when the constitutive activity was removed, 34a behaved as an agonist by increasing the $\left[{ }^{35} \mathrm{~S}\right] \mathrm{GTP} Y \mathrm{~S}$ binding and inhibiting the forskolin-induced cAMP formation (Figure 8A, B). This dual effect is a typical feature of 'protean agonists' [29]. In the $\beta$-arrestin assay, 34a did not show any significant effect despite a tendency to weakly reduce $\beta$-arrestin recruitment by $10 \%$ (Figure $8 \mathrm{C}$ ). The $\mathrm{IC}_{50}$ values of $27 \mathbf{a}$ and 34a for the $\left[{ }^{35} \mathrm{~S}\right] \mathrm{GTP} \gamma \mathrm{S}$ assay and cAMP assay are reported in Table 1. All three compounds (27a, 32, and 34a) did not show any significant interaction with other components of the ECS apart from the magnolol derivative (32) which weakly inhibited the $\left[{ }^{3} \mathrm{H}\right] \mathrm{AEA}$ uptake $\left(\mathrm{IC}_{50}\right.$ value of $6.3(3.2$ to 9.2$\left.) \mu \mathrm{M}\right)$ similarly to $\mathrm{MH}$. Similarly to $\mathrm{MH}$, also compound 32 showed the same potency of inhibiting $\left[{ }^{3} \mathrm{H}\right] \mathrm{AEA}$ uptake in U937 cells and U937-derived macrophages $\left(\mathrm{EC}_{50}\right.$ value of 2.4 (0.9 to $6.1 \mu \mathrm{M})$ (Additional file 1: Figure S5). 


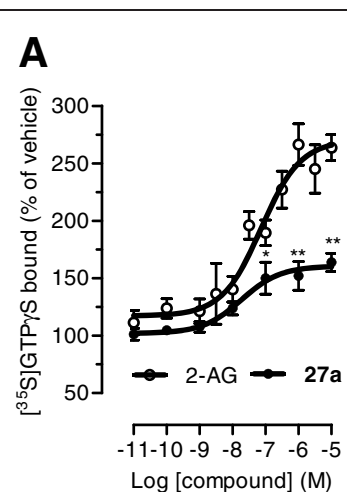

B

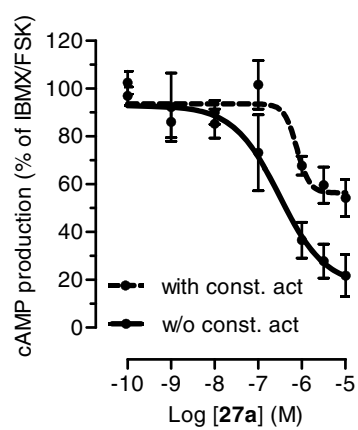

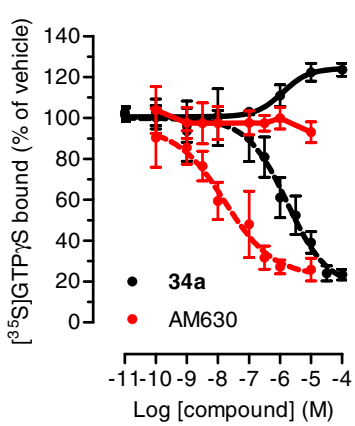
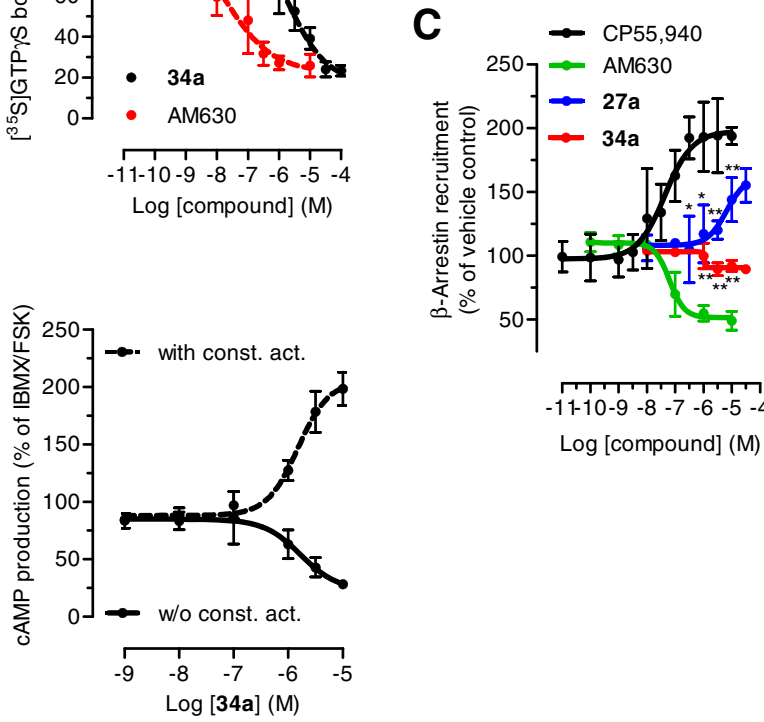

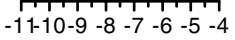

Log [compound] (M)

Figure 8 Modulation of $\mathrm{CB}_{2}$ receptor activity by $\mathbf{2 7 a}$ and $\mathbf{3 4 a}$. (A) $\left.{ }^{35} \mathrm{~S}\right] \mathrm{GTPYS}$ binding assay performed in $\mathrm{CHO}^{\mathrm{K}} \mathrm{K}$ membranes containing $h \mathrm{CB}_{2}$ receptors, in the presence of different concentrations of $\mathbf{2 7}$ a and $\mathbf{3 4 a}$. The $\mathrm{CB}_{2}$ inverse agonist $A M 630$ is reported as positive control (red line). Experiments were performed in the presence (dotted line) and in the absence (solid line) of constitutive activity of the receptors. (B) Inhibition of forskolin-induced cAMP formation by $\mathbf{2 7 a}$ and $\mathbf{3 4 a}$ in $\mathrm{CHO}^{-} h \mathrm{CB}_{2}$ cells transfected with pGloSensorTM 22-F plasmid. The experiments were performed in the presence (dotted line) and in the absence (solid line) of constitutive activity. (C) $\beta$-arrestin recruitment induced by increasing concentrations of $\mathbf{2 7 a}$ and $\mathbf{3 4 a}$, measured in PathHunter ${ }^{\circledR} \beta$-arrestin cells (CHO-K1-HOMSA-CNR2). ${ }^{*} P<0.05,{ }^{* *} P<0.01$ 27a vs. 2-AG (Figure 8A); ${ }^{*} P<0.05,{ }^{* *} P<0.01$ 27a and 34a vs. CP55, 940 (Figure 8C).

\section{Discussion}

$\mathrm{MH}$ is a selective and potent $\mathrm{CB}_{2}$ ligand which was originally described as a full agonist at intracellular $\left[\mathrm{Ca}^{2+}\right]$ and an inverse agonist at Gi/o recruitment by Schuehly et al. [1]. Recently, another group reported the agonist behavior of $\mathrm{MH}$ also on the cAMP pathway [9]. In the present study, using different standardized receptor signaling assays, we found that $\mathrm{MH}$ behaves as a partial agonist in the $\left[{ }^{35} \mathrm{~S}\right] \mathrm{GTP} \mathrm{S}$ binding in overexpressing systems and native conditions and in $\beta$-arrestin recruitment assays, while acting as a full agonist at the cAMP pathway. Similar differential actions between the G-protein recruitment and adenylate cyclase modulation have been reported for other GPCRs like. For example, morphine and fentanyl induced total inhibition of cAMP formation upon binding to $\mu$-opioid receptors, while only showing $75 \%$ to $80 \%$ of maximal G-protein activation compared to the full agonist etorphine [38]. The $\left[{ }^{35} \mathrm{~S}\right] \mathrm{GTP} \gamma \mathrm{S}$ binding assay monitors the first step of G-protein activation but does not provide further information about the downstream signaling pathways which can be differently affected by different ligands. Thus, GPCRs may be coupled prevalently with one type of G-protein, but depending on the system (native vs. overexpressing) and the type of tissue, the same receptor might activate different types of Gprotein $[28,30]$. For example, $\mathrm{CB}_{1}$ receptors are usually coupled to $\mathrm{Gi} / \mathrm{o}$ but under certain conditions can also recruit stimulatory G-protein [39,40], or can induce pertussis toxin-independent increase of intracellular $\left[\mathrm{Ca}^{2+}\right]$ via $\mathrm{Gq} / 11$ recruitment [41]. It has been reported that $\mathrm{CB}_{1}$ receptors expressed in HEK-293 cells can transduce the signal via Gi/o when activated by CP55,940, 2-AG, or $\Delta^{9}$ THC, while WIN55,212-2 induced a $\mathrm{CB}_{1}$-mediated Gq/11 signaling [41]. This suggests that different ligands can trigger distinct active conformations of the receptor which, in turn, can recruit different types of G-proteins. In addition, ligands can also alternatively transduce the signal either via $\mathrm{G} \alpha$ - or $\mathrm{G} \beta \gamma$-subunit as it was recently proposed for $\Delta^{9}$-THC and 2-AG which modulate COX-2 expression in opposite ways by activating $\mathrm{CB}_{1}$ receptors in neurons [42]. The level of complexity is also raised by G-proteinindependent signaling pathways such as $\beta$-arrestin, whose receptor-mediated recruitment can modulate several downstream effectors (e.g., MAPK, ERK1/2, PI3K) besides its role in the desensitization and internalization process (see [43] for review). The introduction of the biased 
agonism' (or functional selectivity) concept triggered a shift from the classic definition of agonism, antagonism, and inverse agonism towards the characterization of ligands which can preferentially activate only one (or few) signaling pathways [44]. It is well established that $\mathrm{CB}_{2}$ receptors possess high levels of constitutive activity and a high degree of trafficking from intracellular pools to the membrane surface and vice versa [45]. As reported by Schuehly et al. [1], $\mathrm{MH}$ and 27a inhibit osteoclastogenesis by acting as inverse agonists on the $\mathrm{CB}_{2}$-mediated cAMP pathway. We now show that both ligands behave as full agonists by inhibiting cAMP formation in the presence or in the absence of constitutive $\mathrm{CB}_{2}$ activation. On the other hand, $\mathrm{MH}$ and 27a show partial agonism for G-protein activation and $\beta$-arrestin recruitment. Partial agonists are very ductile pharmacological tools which can modulate the activation state of a certain receptor in both ways. Indeed, $\mathrm{MH}$ could either potentiate or attenuate the $\mathrm{CB}_{2}$ mediated G-protein recruitment triggered by residual 2AG, depending on the concentration ratio between the two ligands. This pharmacological feature might at least in part explain the discrepancy between the different effects reported for $\mathrm{MH}$ at $\mathrm{CB}_{2}$ receptors (agonist vs. inverse agonist), due to the presence of high or low amounts of 2AG in the culture medium. We recently reported that fetal bovine serum (FBS) contains ECs, and, depending on the batch, the levels of 2-AG can even reach sub-micromolar concentrations [46]. Culturing RAW264.7 cells with 2-AG high-content sera led to significant formation of osteoclasts [46]. In this scenario, the partial agonists $\mathrm{MH}$ and 27a might exert their anti-osteoclastogenesis effects indirectly by blocking 2-AG-induced $\mathrm{CB}_{2}$-mediated osteoclastogenesis. Our current results also suggest that alternative signaling pathways than cAMP might be involved. In line with this hypothesis, Schuehly et al. [1] reported the agonistic behavior of $\mathrm{MH}$ on $\mathrm{CB}_{2}$-mediated increase of intracellular $\left[\mathrm{Ca}^{2+}\right]$, while here, we report that $\mathrm{MH}$ triggers the recruitment of $\beta$-arrestin, which might contribute to the modulation of different downstream effectors. In addition, we described that the 2-O-butyl honokiol derivative (34a) acts as a 'protean agonist' as it could behave as an agonist or inverse agonist, depending on the proportion of constitutively activated $\mathrm{CB}_{2}$ receptors. On the contrary the $\mathrm{CB}_{2}$ inverse agonist AM630 switched from an inverse agonist to an inactive ligand upon the removal of the constitutive activity of the receptors in both $\left[{ }^{35} \mathrm{~S}\right] \mathrm{GTP} \gamma \mathrm{S}$ and cAMP assays (see Figure 8A and Additional file 1: Figure S1), thus confirming that 34a is not simply behaving as an inverse agonist. Noteworthy, upon i.p. application, $\mathrm{MH}$ treatment significantly increased the brain levels of 2-AG in a concentration-dependent manner without significantly affecting $\mathrm{AEA}, \mathrm{AA}, \mathrm{PGE}_{2}$, and corticosterone levels. These findings clearly suggest that the inhibition of COX-2-mediated oxygenation as metabolic pathway for EC degradation in conditions of inflammation is a relevant target for $\mathrm{MH}$. Unfortunately, in vivo we and others could not detect $\mathrm{PGE}_{2}-\mathrm{GE}$, probably due to an extensive hydrolysis to the related arachidonoyl derivative $\left(\mathrm{PGE}_{2}\right)$, as previously shown $[47,48]$. Also, the effect of SSIs may turn out to be different, dependent on mouse strains. Recently, Hermanson et al. [21] reported using a morpholino amide derivative of indomethacin, LM-4131, a 150\% increase of AEA levels and only minor effects on 2-AG levels ( 110\%) in imprinting control region (ICR) mouse brain. In normal conditions, 2-AG predominantly undergoes hydrolytic degradation $[49,50]$, but upon LPS-challenge, COX-2 levels significantly rise in neurons [51] and astrocytes/microglial cells [52], thus increasing the relevance of the oxygenation pathway. In our setting we detected a significant increase of 2 -AG levels by $170 \%$ and $200 \%$ upon treatment with 10 and $20 \mathrm{mg} \mathrm{kg}^{-1}$ of $\mathrm{MH}$, respectively. AEA levels were not significantly changed by $\mathrm{MH}$ treatment despite a tendency to increase (120\%) at the dose of 20

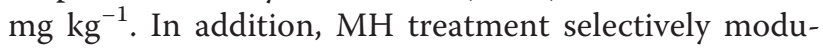
lated the levels of 2-AG without affecting the levels of AA, $\mathrm{PGE}_{2}$, the FAAH-substrates $\mathrm{N}$-acetylethanolamines, and corticosterone. Therefore, SSI of COX-2 activity appears to be a promising strategy to modulate EC levels in the brain, especially under inflammatory conditions. Prostamides and PG-GEs play an active role in the inflammatory process both in vitro and in vivo by acting through $\mathrm{CB}_{1 / 2}$ receptor-independent targets $[15,19,53]$. In hippocampal neurons, COX-2 inhibition rather than FAAH blockage led to a prolonged depolarization-induced suppression of inhibition suggesting a prominent role of $2-\mathrm{AG}$ in the retrograde signal and COX-2-mediated oxygenation as relevant mechanism of reducing 2-AG levels at the synaptic level [54]. Straiker et al. [55] also reported the relevant role of COX-2 activity in reducing EC-mediated retrograde signaling. Recently it was shown that $\mathrm{MH}$ can weakly potentiate GABA-induced chloride currents in Xenopus oocytes by acting at the most common $\alpha_{1} \beta_{2} \gamma_{2}$ GABA $_{A}$ receptor subtype [8]. In an animal model, repeated low doses $\left(0.5 \mathrm{mg} \mathrm{kg}^{-1}\right.$ per os) of MH produced weak anxiolytic effects [56] similar to the SSI LM-4131 [21]. Thus, MH could represent a prototype of multi-target compound which can directly and indirectly potentiate the ECS. Nonetheless, the pharmacokinetic profile of $\mathrm{MH}$ indicates a poor oral bioavailability and extensive hepatic metabolism in rats [57]. Our data show that upon i.p. injection, $\mathrm{MH}$ penetrates the brain at concentrations which are in line with the effects on $\mathrm{CB}_{2}$ receptors and the SSI of COX-2 activity (approximately 200 and $300 \mathrm{nM}$ for 10 and $20 \mathrm{mg} \mathrm{kg}^{-1}$, respectively). Mice were sacrificed $7 \mathrm{~h}$ after the injection, thus indicating that $\mathrm{MH}$ could reach and accumulate in the brain without being significantly metabolized. 
Despite the reported poor bioavailability after single oral administration [57], upon repeated doses, MH might accumulate and exert pharmacological effects in the brain. This could also explain the beneficial effects reported for long-term treatment with low doses of $\mathrm{MH}$ administered per os $(0.1$ to $1 \mathrm{mg} \mathrm{kg}$ ) in neurodegenerative animal models $[2,4,36] . \mathrm{CB}_{2}$ receptors are almost absent in the CNS under normal conditions, but upon inflammation, they are significantly upregulated in microglial cells. Neuroinflammation is a hallmark of neurodegenerative diseases which contributes to the onset and progression of the disease $[58,59]$ and several results support the positive role of $\mathrm{CB}_{2}$ activation in neurodegenerative diseases including the stimulation of $\beta$-amyloid removal by macrophages and down-regulation of TNF- $\alpha$ production [60-62]. MH showed beneficial effects in Alzheimer's disease (AD) models by reducing LPS-induced $\beta$-amyloid accumulation, pro-inflammatory cytokine production, and memory impairment $[2,4]$. Since in addition to the direct activation of $\mathrm{CB}_{2}$ receptors, $\mathrm{MH}$ also elevates 2-AG levels, which is the main endogenous agonist for $\mathrm{CB}_{2}$, and it further inhibits the formation of pro-inflammatory PG-EAs and PG-GEs; synergistic effects for attenuating the inflammatory process are expected to represent one of the main underlying mechanisms of the neuroprotective effects exerted by $\mathrm{MH}$. Interestingly, $(R)$-flurbiprofen is a COX-2 SSI with negligible effects on AA metabolism [14] which showed COX-2-independent anti-inflammatory effects in $\mathrm{AD}$ and experimental autoimmune encephalomyelitis multiple sclerosis models [63-65]. Remarkably, in this model, $(R)$-flurbiprofen induced a significant increase of EC levels in the spinal cord and somatosensory cortex while only mildly affecting PGs levels [65]. Therefore, based on our data we suggest that the major mode of action related to the pronounced neuroprotective effects of $\mathrm{MH}$ may be related to its outstanding polypharmacology in the ECS.

\section{Conclusions}

We show for the first time that $\mathrm{MH}$ penetrates the blood-brain barrier and accumulates in the brain in amounts that are consistent with the concentrations that modulate the ECS in vitro. MH might serve as prototype scaffold to develop compounds exhibiting a novel combination of polypharmacology to modulate the ECS through a concurrent activation of $\mathrm{CB}_{2}$ receptors and the SSI of COX-2-mediated EC oxygenation. For MH, the latter mechanism was shown here for the first time both in vitro and in vivo. This polypharmacology might achieve synergistic anti-inflammatory and protective actions in certain tissues, including the brain, by directly and indirectly (increasing 2-AG levels) activating $\mathrm{CB}_{2}$ receptors, avoiding the typical gastrointestinal and cardiovascular side effects of NSAIDs. Moreover, these two mechanisms of action might be more relevant in neuroinflammatory diseases where both $\mathrm{COX}-2$ and $\mathrm{CB}_{2}$ receptors are overexpressed in the brain, thus providing a rationale for the diverse neuroprotective effects reported for $\mathrm{MH}$ in animal models.

\section{Additional file}

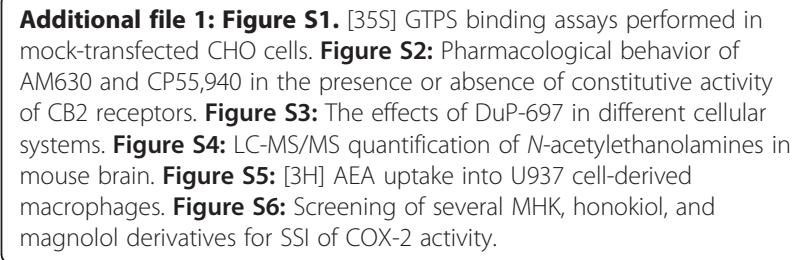

\section{Abbreviations}

AA: arachidonic acid; AD: Alzheimer's disease; ABHDs: a, $\beta$-hydrolases;

AEA: anandamide; 2-AG: 2-arachidonoyl glycerol; AM630: [6-iodo-2-methyl-1-[2-(4morpholinyl) ethyl]-1H-indol-3-yl] (4-methoxyphenyl)-methanone; cAMP: cyclic AMP; BSA: bovine serum albumin; $\mathrm{CB}_{1}$ : type-1 cannabinoid receptor; $\mathrm{CB}_{2}$ : type-2 cannabinoid receptor; CP55: 940, (-)-cis-3-[2-hydroxy-4-(1,1 dimethylheptyl) phenyl]-trans-4-(3-hydroxypropyl) cyclohexanol; COX-2: cyclooxygenase-2; CNS: central nervous system; EC: endocannabinoid; ECS: endocannabinoid system; FAAH: fatty acid amide hydrolase; FSK: forskolin; ICR: imprinting control region; IS: internal standard; JZL184: 4-nitrophenyl-4-[bis (1,3-benzodioxol-5-yl) (hydroxy) methyl] piperidine-1-carboxylate; MAGL: monoacylglycerol lipase; $\mathrm{MH}$ : 4'-Omethylhonokiol; MRM: multiple reaction monitoring; NA-GABA: N-arachidonoyl GABA; NSAIDs: non-steroidal anti-inflammatory drugs; PGs: prostaglandins; PGEAs: prostaglandin-ethanolamides (prostamides); PG-GEs: prostaglandin glycerol esters; SSI: substrate selective inhibition/inhibitor; UCM707: (5Z, 8Z, 11Z, 14Z)-N-(3furanylmethyl)-5,8,11,14-eicosatetraenamide; URB597: (3'-(aminocarbonyl) [1, 1'-biphenyl]-3-yl)-cyclohexylcarbamate; WIN55212-2: (R)-(+)-[2, 3dihydro-5-methyl-3-(4-morpholinylmethyl) pyrrolo-[1,2,3-de]-1,4-benzoxazin-6-yl]-1-naphtaleneylmethanone; WWL70: N-methyl-N-[[3-(4-pyridinyl) phenyl] methyl]-carbamic acid 4' - (aminocarbonyl) [1, 1'-biphenyl]-4-yl ester.

\section{Competing interests}

The authors declare that they have no competing interests.

\section{Authors' contributions}

AC, MSG, VP, and RPC performed the experiments; JG and AC designed the research study; WS contributed the essential tools; AC, MSG, and JG analyzed the data; $A C$ and JG wrote the paper. All authors read and approved the final manuscript.

\section{Acknowledgements}

We would like to acknowledge Christoph Ullmer and Uwe Grether from F. Hoffmann-La-Roche Ltd. for independently confirming our data with $\mathrm{MH}$ in their CAMP assays. We thank Antje Hüfner (University of Graz) for synthesizing the $\mathrm{MH}-\mathrm{d} 6$ standard. Finally, we would like to thank Stefano Chicca for performing $\left[{ }^{35}\right.$ S] GTPYS assays in spleen membranes.

\section{Author details}

${ }^{1}$ Institute of Biochemistry and Molecular Medicine, NCCR TransCure, University of Bern, Bühlstrasse 28, CH-3012 Bern, Switzerland. ${ }^{2}$ Institute of Zoology, Karl-Franzens-University Graz, Universitätsplatz 2, 8010 Graz, Austria.

Received: 6 February 2015 Accepted: 24 April 2015

Published online: 13 May 2015

\section{References}

1. Schuehly W, Paredes JM, Kleyer J, Huefner A, Anavi-Goffer S, Raduner S, et al. Mechanisms of osteoclastogenesis inhibition by a novel class of biphenyl-type cannabinoid CB (2) receptor inverse agonists. Chem Biol. 2011;18:1053-64 
2. Lee YJ, Choi DY, Choi IS, Kim KH, Kim YH, Kim HM, et al. Inhibitory effect of 4-O-methylhonokiol on lipopolysaccharide-induced neuroinflammation, amyloidogenesis and memory impairment via inhibition of nuclear factorkappaB in vitro and in vivo models. J Neuroinflammation. 2012;9:35.

3. Lee YJ, Choi DY, Lee YK, Lee YM, Han SB, Kim YH, et al. 4-O-methylhonokiol prevents memory impairment in the Tg2576 transgenic mice model of Alzheimer's disease via regulation of $\beta$-secretase activity. J Alzheimers Dis. 2012;29:677-90.

4. Jung YY, Lee YJ, Choi DY, Hong JT. Amelioration of cognitive dysfunction in APP/ps1 double transgenic mice by long-term treatment of 4-OMethylhonokiol. Biomol Ther (Seoul). 2014;22:232-8.

5. Gertsch J, Anavi-Goffer S. Methylhonokiol attenuates neuroinflammation: a role for cannabinoid receptors? J Neuroinflammation. 2012;9:135.

6. Kim HS, Ryu HS, Kim JS, Kim YG, Lee HK, Jung JK, et al. Validation of cyclooxygenase-2 as a direct anti-inflammatory target of 4-O-methylhonokiol in zymosan-induced animal models. Arch Pharm Res. 2014. In press.

7. Schühly W, Hüfner A, Pferschy-Wenzig EM, Prettner E, Adams M, Bodensieck A, et al. Design and synthesis of ten biphenyl-neolignan derivatives and their in vitro inhibitory potency against cyclooxygenase-1/2 activity and 5lipoxygenase-mediated LTB4-formation. Bioorg Med Chem. 2009;17:4459-65.

8. Baur R, Schuehly W, Sigel E. Moderate concentrations of 4-Omethylhonokiol potentiate GABAA receptor currents stronger than honokiol. Biochim Biophys Acta. 2014;1840:3017-21.

9. Fuchs A, Rempel V, Müller CE. The natural product magnolol as a lead structure for the development of potent cannabinoid receptor agonists. PLoS One. 2013;8:e77739.

10. Kozak KR, Crews BC, Morrow JD, Wang LH, Ma YH, Weinander R, et al. Metabolism of the endocannabinoids, 2-arachidonylglycerol and anandamide, into prostaglandin, thromboxane, and prostacyclin glycerol esters and ethanolamides. J Biol Chem. 2002;277:44877-85.

11. Kozak KR, Gupta RA, Moody JS, Ji C, Boeglin WE, DuBois RN, et al. 15Lipoxygenase metabolism of 2-arachidonylglycerol. Generation of a peroxisome proliferator-activated receptor alpha agonist. J Biol Chem. 2002;277:23278-86.

12. Snider NT, Walker VJ, Hollenberg PF. Oxidation of the endogenous cannabinoid arachidonoyl ethanolamide by the cytochrome P450 monooxygenases: physiological and pharmacological implications. Pharmacol Rev. 2010;62:136-54.

13. Weber A, Ni J, Ling KH, Acheampong A, Tang-Liu DD, Burk R, et al. Formation of prostamides from anandamide in FAAH knockout mice analyzed by HPLC with tandem mass spectrometry. J Lipid Res. 2004;45:757-63.

14. Duggan KC, Hermanson DJ, Musee J, Prusakiewicz JJ, Scheib JL, Carter BD, et al. (R)-Profens are substrate-selective inhibitors of endocannabinoid oxygenation by COX-2. Nat Chem Biol. 2011;7:803-9.

15. Gatta L, Piscitelli F, Giordano C, Boccella S, Lichtman A, Maione S, et al. Discovery of prostamide F2a and its role in inflammatory pain and dorsal horn nociceptive neuron hyperexcitability. PLoS One. 2012;7:e31111.

16. Kaufmann WE, Worley PF, Pegg J, Bremer M, Isakson P. COX-2, a synaptically induced enzyme, is expressed by excitatory neurons at postsynaptic sites in rat cerebral cortex. Proc Natl Acad Sci U S A. 1996;93:2317-21.

17. Yoshikawa K, Takei S, Hasegawa-Ishii S, Chiba Y, Furukawa A, Kawamura N, et al. Preferential localization of prostamide/prostaglandin $\mathrm{F}$ synthase in myelin sheaths of the central nervous system. Brain Res. 2011;1367:22-32.

18. Ritter JK, Li C, Xia M, Poklis JL, Lichtman AH, Abdullah RA, et al. Production and actions of the anandamide metabolite prostamide E2 in the renal medulla. J Pharmacol Exp Ther. 2012;342:770-9.

19. Liang Y, Woodward DF, Guzman VM, Li C, Scott DF, Wang JW, et al. Identification and pharmacological characterization of the prostaglandin FP receptor and FP receptor variant complexes. Br J Pharmacol. 2008;154:1079-93.

20. Ligresti A, Martos J, Wang J, Guida F, Allarà M, Palmieri V, et al. Prostamide F (2) a receptor antagonism combined with inhibition of FAAH may block the pro-inflammatory mediators formed following selective FAAH inhibition. Br J Pharmacol. 2014;171:1408-19.

21. Hermanson DJ, Hartley ND, Gamble-George J, Brown N, Shonesy BC, Kingsley PJ, et al. Substrate-selective COX-2 inhibition decreases anxiety via endocannabinoid activation. Nat Neurosci. 2013;16:1291-8.

22. Chicca A, Caprioglio D, Minassi A, Petrucci V, Appendino G, Taglialatela-Scafati O, et al. Functionalization of $\beta$-caryophyllene generates novel polypharmacology in the endocannabinoid system. ACS Chem Biol. 2014;9:1499-507.

23. Chicca A, Marazzi J, Gertsch J. The antinociceptive triterpene $\beta$-amyrin inhibits 2-arachidonoylglycerol (2-AG) hydrolysis without directly targeting cannabinoid receptors. Br J Pharmacol. 2002;167:1596-608.
24. Rosati O, Messina F, Pelosi A, Curini M, Petrucci V, Gertsch J, et al. One-pot heterogeneous synthesis of $\Delta$ (3)-tetrahydrocannabinol analogues and xanthenes showing differential binding to $C B(1)$ and $C B(2)$ receptors. Eur J Med Chem. 2014;85:77-86.

25. Gachet MS, Rhyn P, Bosch OG, Quednow BB, Gertsch J. A quantitiative LC-MS/MS method for the measurement of arachidonic acid, prostanoids, endocannabinoids, $\mathrm{N}$-acylethanolamines and steroids in human plasma. J Chromatogr, B. 2015;976-977:6-18.

26. Seifert R, Wenzel-Seifert K, Gether U, Kobilka BK. Functional differences between full and partial agonists: evidence for ligand-specific receptor conformations. J Pharmacol Exp Ther. 2001;297:1218-26.

27. Munro S, Thomas KL, Abu-Shaar M. Molecular characterization of a peripheral receptor for cannabinoids. Nature. 1993;365:61-5.

28. Marini P, Cascio MG, King A, Pertwee RG, Ross RA. Characterization of cannabinoid receptor ligands in tissues natively expressing cannabinoid CB2 receptors. Br J Pharmacol. 2013;169:887-99.

29. Kenakin T. Functional selectivity through protean and biased agonism: who steers the ship? Mol Pharmacol. 2007;72:1393-13401.

30. Mancini I, Brusa R, Quadrato G, Foglia C, Scandroglio P, Silverman LS, et al. Constitutive activity of cannabinoid-2 (CB2) receptors plays an essential role in the protean agonism of (+) AM1241 and L768242. Br J Pharmacol. 2009;158:382-91.

31. Yao BB, Mukherjee S, Fan Y, Garrison TR, Daza AV, Grayson GK, et al. In vitro pharmacological characterization of AM1241: a protean agonist at the cannabinoid CB2 receptor? Br J Pharmacol. 2006;149:145-54.

32. Bolognini D, Cascio MG, Parolaro D, Pertwee RG. AM630 behaves as a protean ligand at the human cannabinoid CB2 receptor. Br J Pharmacol. 2012;165:2561-74.

33. Silvestri C, Martella A, Poloso NJ, Piscitelli F, Capasso R, Izzo A, et al. Anandamide-derived prostamide F2a negatively regulates adipogenesis. J Biol Chem. 2014;288:23307-21.

34. Nomura DK, Morrison BE, Blankman JL, Long JZ, Kinsey SG, Marcondes MC, et al. Endocannabinoid hydrolysis generates brain prostaglandins that promote neuroinflammation. Science. 2011;334:809-13.

35. Cabrera R, Korte SM, Lentjes EG, Romijn F, Schönbaum E, De Nicola A, et al. The amount of free corticosterone is increased during lipopolysaccharideinduced fever. Life Sci. 2002;66:553-62.

36. Lee YK, Choi IS, Ban JO, Lee HJ, Lee US, Han SB, et al. 4-O-methylhonokiol attenuated $\beta$-amyloid-induced memory impairment through reduction of oxidative damages via inactivation of p38 MAP kinase. J Nutr Biochem. 2011;22:476-86

37. Chicca A, Marazzi J, Nicolussi S, Gertsch J. Evidence for bidirectional endocannabinoid transport across cell membranes. J Biol Chem. 2012;287:34660-82.

38. Zaki PA, Keith Jr DE, Brine GA, Carroll Fl, Evans CJ. Ligand-induced changes in surface mu-opioid receptor number: relationship to G protein activation? J Pharmacol Exp Ther. 2000;292:1127-34.

39. Felder CC, Joyce KE, Briley EM, Glass M, Mackie KP, Fahey K, et al. LY320135, a novel cannabinoid $\mathrm{CB} 1$ receptor antagonist, unmasks coupling of the CB1 receptor to stimulation of CAMP accumulation. J Pharmacol Exp Ther. 1998;284:291-7.

40. Bauer M, Chicca A, Tamborrini M, Eisen D, Lerner R, Lutz B, et al. Identification and quantification of a new family of peptide endocannabinoids (Pepcans) showing negative allosteric modulation at CB1 receptors. J Biol Chem. 2012;287:36944-9667.

41. Lauckner JE, Hille B, Mackie K. The cannabinoid agonist WIN55,212-2 increases intracellular calcium via CB1 receptor coupling to Gq/11 G proteins. Proc Natl Acad Sci U S A. 2005;102:19144-9.

42. Chen R, Zhang J, Fan N, Teng ZQ, Wu Y, Yang H, et al. $\Delta$ 9-THC-caused synaptic and memory impairments are mediated through COX-2 signaling. Cell. 2014;155:1154-65.

43. Reiter E, Ahn S, Shukla AK, Lefkowitz RJ. Molecular mechanism of $\beta$-arrestinbiased agonism at seven-transmembrane receptors. Annu Rev Pharmacol Toxicol. 2012;52:179-97.

44. Kenakin T, Christopoulos A. Signalling bias in new drug discovery: detection, quantification and therapeutic impact. Nat Rev Drug Discov. 2013;12:205-16.

45. Kleyer J, Nicolussi S, Taylor P, Simonelli D, Furger E, Anderle P, et al. Cannabinoid receptor trafficking in peripheral cells is dynamically regulated by a binary biochemical switch. Biochem Pharmacol. 2012;83:1393-412.

46. Marazzi J, Kleyer J, Paredes JM, Gertsch J. Endocannabinoid content in fetal bovine sera - unexpected effects on mononuclear cells and osteoclastogenesis. J Immunol Methods. 2011;373:219-28. 
47. Kozak KR, Crews BC, Ray JL, Tai HH, Morrow JD, Marnett LJ. Metabolism of prostaglandin glycerol esters and prostaglandin ethanolamides in vitro and in vivo. J Biol Chem. 2001;276:36993-8.

48. Savinainen JR, Kansanen E, Pantsar T, Navia-Paldanius D, Parkkari T, Lehtonen M, et al. Robust hydrolysis of prostaglandin glycerol esters by human monoacylglycerol lipase (MAGL). Mol Pharmacol. 2014:86:522-35.

49. Long JZ, Li W, Booker L, Burston JJ, Kinsey SG, Schlosburg JE, et al. Selective blockade of 2-arachidonoylglycerol hydrolysis produces cannabinoid behavioral effects. Nat Chem Biol. 2009;5:37-44.

50. Marrs WR, Blankman JL, Horne EA, Thomazeau A, Lin YH, Coy J, et al. The serine hydrolase ABHD6 controls the accumulation and efficacy of 2-AG at cannabinoid receptors. Nat Neurosci. 2010;13:951-7.

51. Du H, Chen X, Zhang J, Chen C. Inhibition of COX-2 expression by endocannabinoid 2-arachidonoylglycerol is mediated via PPAR- $\gamma$. Br J Pharmacol. 2011;163:1533-49.

52. Font-Nieves M, Sans-Fons MG, Gorina R, Bonfill-Teixidor E, Salas-Pérdomo A, Márquez-Kisinousky L, et al. Induction of COX-2 enzyme and downregulation of COX-1 expression by lipopolysaccharide (LPS) control prostaglandin E2 production in astrocytes. J Biol Chem. 2012;287:6454-68.

53. Woodward DF, Carling RW, Cornell CL, Fliri HG, Martos JL, Pettit SN, et al. The pharmacology and therapeutic relevance of endocannabinoid derived cyclo-oxygenase (COX)-2 products. Pharmacol Ther. 2008;1 20:71-80.

54. Kim J, Alger BE. Inhibition of cyclooxygenase-2 potentiates retrograde endocannabinoid effects in hippocampus. Nat Neurosci. 2004;7:697-8.

55. Straiker A, Wager-Miller J, Hu SS, Blankman JL, Cravatt BF, Mackie K. COX-2 and fatty acid amide hydrolase can regulate the time course of depolarization-induced suppression of excitation. Br J Pharmacol. 2011:164:1672-83.

56. Han H, Jung JK, Han SB, Nam SY, Oh KW, Hong JT. Anxiolytic-like effects of 4-Omethylhonokiol isolated from Magnolia officinalis through enhancement of GABAergic transmission and chloride influx. J Med Food. 2011;14:724-31.

57. Yu HE, Oh SJ, Ryu JK, Kang JS, Hong JT, Jung JK, et al. Pharmacokinetics and metabolism of 4-O-methylhonokiol in rats. Phytother Res. 2014;28:568-78.

58. Ashton JC, Glass M. The cannabinoid CB2 receptor as a target for inflammation-dependent neurodegeneration. Curr Neuropharmacol. 2007:5(2):73-80

59. Zotova E, Nicoll JA, Kalaria R, Holmes C, Boche D. Inflammation in Alzheimer's disease: relevance to pathogenesis and therapy. Alzheimers Res Ther. 2010;2(1):1. doi:10.1186/alzrt24.

60. Rom S, Persidsky Y. Cannabinoid receptor 2: potential role in immunomodulation and neuroinflammation. J Neuroimmune Pharmacol. 2013;8:608-20

61. Gowran A, Noonan J, Campbell VA. The multiplicity of action of cannabinoids: implications for treating neurodegeneration. CNS Neurosci Ther. 2011;17:637-44.

62. Aso E, Juvés S, Maldonado R, Ferrer I. CB2 cannabinoid receptor agonist ameliorates Alzheimer-like phenotype in AßPP/PS1 mice. J Alzheimers Dis. 2013:35(4):847-58, doi:10.3233/JAD-130137.

63. Carreras I, McKee AC, Choi JK, Aytan N, Kowall NW, Jenkins BG, et al. R-flurbiprofen improves tau, but not $A B$ pathology in a triple transgenic model of Alzheimer's disease. Brain Res. 2013;1541:115-27.

64. Kukar T, Prescott S, Eriksen JL, Holloway V, Murphy MP, Koo EH, et al. Chronic administration of R-flurbiprofen attenuates learning impairments in transgenic amyloid precursor protein mice. BMC Neurosci. 2007;8:54.

65. Schmitz K, de Bruin N, Bishay P, Männich J, Häussler A, Altmann C, et al. R-flurbiprofen attenuates experimental autoimmune encephalomyelitis in mice. EMBO Mol Med. 2014:6:1398-422.

\section{Submit your next manuscript to BioMed Central and take full advantage of:}

- Convenient online submission

- Thorough peer review

- No space constraints or color figure charges

- Immediate publication on acceptance

- Inclusion in PubMed, CAS, Scopus and Google Scholar

- Research which is freely available for redistribution 